\title{
Herpetofauna of the southern Carnarvon Basin, Western Australia
}

\author{
N.L. McKenzie' ${ }^{1}$, J.K. Rolfe ${ }^{1}$, K.P. Aplin' ${ }^{2}$, M.A. Cowan ${ }^{2}$ and L.A. Smith ${ }^{2}$ \\ ${ }^{1}$ Department of Conservation and Land Management, P.O. Box 51, Wanneroo, \\ Western Australia 6065, Australia \\ ${ }^{2}$ Western Australian Museum, Francis Street, Perth, Western Australia 6000, Australia
}

\begin{abstract}
We sampled the frog and reptile species on 63 quadrats chosen to represent the geographical extent and diversity of terrestrial environments in a $75000 \mathrm{~km}^{2}$ study area in the Carnarvon Basin. Twelve frog and 17 gecko, 10 pygopodid, 16 dragon, 58 skink, four goanna and 16 snake species were recorded, an average of 16.3 species per quadrat.

Patterns in species composition were related to biogeographical, ecological and local evolutionary processes. Four species assemblages were distinguished, each relating to gradients in a different set of precipitation plus soil plus topographic attributes. In these terms, Poisson error models with logarithmic links fitted the relationships. Virtually identical patterns emerged when we re-analysed the data using an ecological taxonomy that was based on functional morphology.

If evolutionary processes are to be protected along with the ecological and biogeographical processes, the reserve system will need to sample the geographical range of the various rainfall, soil and topographic gradients identified by the analyses.
\end{abstract}

\section{INTRODUCTION}

This study explores patterns in the composition of reptilian and amphibian communities in nonaquatic environments of the southern Carnarvon Basin.

The earliest records from the study area were made early last century by naturalists Peron, Quoy and Gaimard accompanying the French navigators Baudin and Freycinet (Storr and Harold, 1978). The German zoologists W. Michaelsen and R. Hartmeyer made the next collections in 1905 (Werner, 1909).

Most of the data available at the outset of this study were derived from specimens collected in the area since the 1950s and lodged in the collections of the Western Australian Museum. Sources included the localised inventories of Bernier and Dorre Island (Douglas and Ride, 1962), Faure Island in 1959 (W.H. Butler, unpublished), Dirk Hartog Island (Burbidge and George, 1978), Edel Land and Hamelin (see Storr and Harold, 1978), and Toolonga Nature Reserve (Burbidge et al., 1980).

The first comprehensive inventories, carried out between 1976 and 1980 by Harold, Peterson and Winton, allowed Storr and Harold (1978, 1980, 1984) to review the biogeographical relationships and habitat-preferences of the amphibian and reptilian species known from the Zuytdorp, Shark Bay and Lake MacLeod Regions. Combined, these three regions cover the same tract of country as our study area.

The first quantitative sampling of herpetofaunal patterns in the study area was carried out by Kendrick (1991), for his dissertation on the biogeography, ecology and systematic relationships of the skink genus Lerista. But the lack of any systematic ecological survey of the entire herpetofauna in terms of the study area's climatic and.geomorphological gradients has precluded any quantitative understanding of the structure and composition of this component of its communities.

By sampling a set of quadrats, positioned to represent the diversity of the study area's physical environments across its geographical extent, we aimed to provide a regional context for conserving the study area's herpetofauna. Specifically, our objectives were to:

- carry out the first systematic survey of species extant in the study area,

- lodge voucher collections in the Western Australian Museum for detailed taxonomic appraisal (Aplin et al., in press),

- provide an overview of the status and distribution of species,

- describe the relationships between species occurrences and attributes of the study area's physical environment, and identify predictors of gradients in species composition across the study area and

- provide a quadrat-based benchmark against which future changes in the status of the herpetofauna can be measured. 


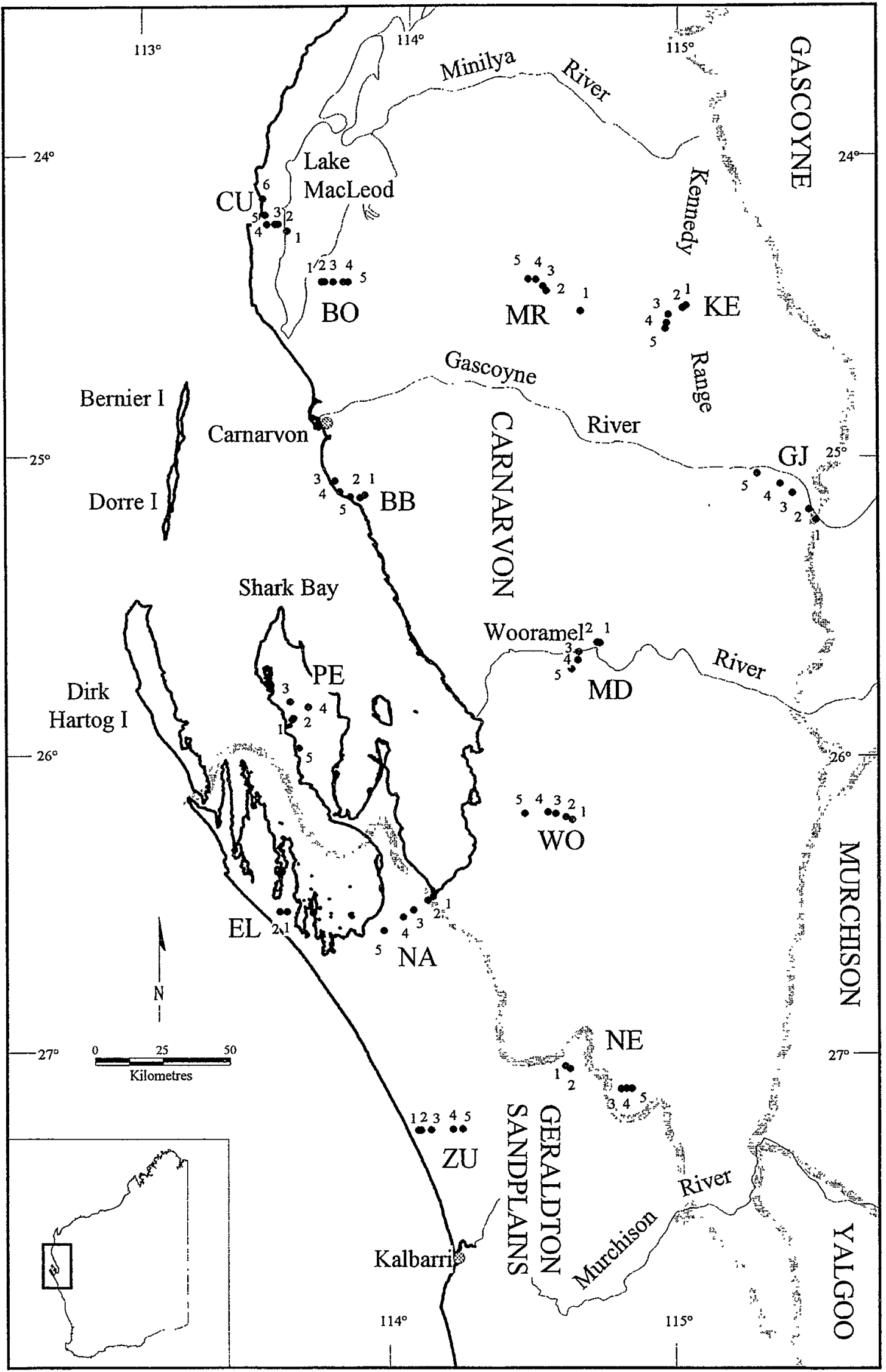

Figure 1 The Carnarvon Basin study area, showing the 13 survey areas (campsites) and individual quadrat positions. Precise quadrat co-ordinates are provided in Appendix A (p. $\$ \$$, this volume). Survey area codes were Bush Bay (BB), Boolathana (BO), Cape Cuvier (CU), Edel Land (EL), Gascoyne Junction (GJ), Kennedy Range (KE), Meedo (MD), Mardathuna (MR), Nanga (NA), Nerren Nerren (NE), Peron Peninsula (PE), Woodleigh (WO) and Zuytdorp (ZU). 


\section{METHODS}

\section{Study Area}

The Carnarvon Basin study area covers 75000 $\mathrm{km}^{2}$ on Australia's western coast. It is centred on Shark Bay, and extends northwards from the Murchison River to the Minilya River, and eastwards to $115^{\circ} 30^{\prime} \mathrm{E}$ (beyond Gascoyne Junction) (Figure 1).

Its physical environments are detailed by Wyrwoll, Courtney and Sandercock (2000) and Wyrwoll, Stoneman, Elliott and Sandercock (2000). Briefly, the region is a lowland characterised by gentle gradients on a basement of soft sediments. Under a variety of climates, interacting alluvial and aeolian processes have produced a complex landscape mosaic, that has been further modified by extensive coastal transgressions associated with sea-level changes. Today, the area south of Shark Bay has a semi-arid climate influenced by temperate weather systems (mainly winter rainfall). From Shark Bay northward, the climate is influenced by both tropical and temperate systems; semi-arid at the coast, but arid with locally unreliable summer and winter rainfall further inland. In phytogeographic terms, the study area comprises the northern half of the Irwin District of the South-western Province, as well as the southern half of the Carnarvon District of the Eremean Province (Beard, 1980).

Extensive alluvial plains dominate the study area, although erosional uplands such as the Kennedy Range occur in its eastern parts. The plains are traversed from east to west by two large, ephemeral rivers: the Gascoyne and Wooramel. Both rivers are lined with groves of River Gum (Eucalyptus victrix). Low open woodlands of bowgada (Acacia linophylla) and snakewood (A. xiphophylla) over Atriplex, Senna and Eremophila shrubs and tussock grasses cover the plains, with Acacia grasbyi in areas where calcretes are exposed. Low red sand ridges scattered across the plains support shrubs over mainly hummockgrasses. In northern parts, the plains grade into red sand dune fields that support hummock-grass and mulga ( $A$. aneura) communities reminiscent of the red centre. In the south the plains support woodlands of Eucalyptus loxophleba and Callitris glaucophylla, with mallee, Banksia, Allocasuarina and Actinostrobus scrubs and heaths on greyish and yellow sand dunes. A strip of limestone that follows the coast southwards from Shark Bay is partially mantled by pale yellow to grey sands supporting low proteaceous heaths with emergent thickets of Banksia and mallees such as Eucalyptus illyarrie. White coastal sand dunes support Spinifex longifolius communities. Low-lying saline areas, such as the fringes of Lake MacLeod and the coastal flats, support samphire and saltbush communities. Detailed descriptions of the vegetations in the study area are provided by Beard $(1975,1976)$, Payne $e t$ al. (1987), Gibson et al. (2000) and Keighery et al. (2000).

\section{Historical Review}

Lists of the species previously captured in the study area were extracted from published literature and from the Western Australian Museum's zoological register.

\section{Field Sampling}

Herpetofauna were sampled on quadrats positioned throughout the geographical extent of the study area in a stratified random array. The quadrats were placed in typical examples of each of the surface stratigraphic units that characterise the study area. Many quadrats were pseudo-replicated (locally as well as at distant points) to allow for the internal heterogeneity of the stratification units (hypothesised scalars) and to minimise any analytical circularity introduced by the stratification (McKenzie et al., 1989, 1991b).

The study area encompassed seven million hectares, and sampling was restricted to 63 relevé quadrats with a combined area of 1008 hectares (each relevé was set in a visually homogeneous 400 $\times 400 \mathrm{~m}$ area $=16$ hectares; $63 \times 16=1008$ ha). Thus, sampling was sparse; no more than $0.014 \%$ of study area was actually sampled. The 63 quadrats were clustered in sets of two to six quadrats around each of 13 survey areas, herein referred to as 'campsites'.

Trapping and hand-foraging (digging, raking etc) were used to detect species' presence-absence on quadrats. Two pitfall-trap arrays were placed on each quadrat. The arrays each comprised a line of 6 PVC tubular pitfall-traps ('tubes'), $125 \mathrm{~mm}$ in diameter and $500 \mathrm{~mm}$ deep, spaced at $10 \mathrm{~m}$ intervals along a $50 \mathrm{~m}$ flywire drift fence that was $300 \mathrm{~mm}$ high. About $5 \mathrm{~m}$ from either side of the 50 $\mathrm{m}$ fence was a "bucket" pitfall-trap $300 \mathrm{~mm}$ in

Table 1 Total number of fenced pitfall-trap nights per sampling session, excluding the 9260 tub-nights in May 1995.

\begin{tabular}{lccccrrr}
\hline Pit-trap Type & Oct 94 & Jan 95 & May 95 & Nov 95 & Mar 96 \\
\hline Buckets & 1220 & 12 & 1244 & - & - & 2476 \\
Tubes & 3660 & 72 & 3704 & 516 & 2736 & 10688 \\
Total & 4880 & 84 & 4948 & 516 & 2736 \\
\hline
\end{tabular}

a see 'Data quality', below.

${ }^{b}$ see Table 2. 
Table 2 Number of fenced pitfall-trap nights per quadrat in early-Autumn 1996 (8-27 March). The total number of fenced pitfall-trap nights completed at each quadrat over the entire sampling programme is included in brackets. Campsite locations are provided in Figure 1.

\begin{tabular}{|c|c|c|c|c|c|c|}
\hline \multirow[t]{2}{*}{ Campsite } & \multicolumn{6}{|c|}{ Quadrat } \\
\hline & 1 & 2 & 3 & 4 & 5 & 6 \\
\hline $\mathrm{BB}$ & $24(184)$ & $84(276)$ & $24(184)$ & $84(244)$ & $48(208)$ & \\
\hline $\mathrm{BO}$ & $36(196)$ & $36(196)$ & $144(304)$ & $192(352)$ & $144(304)$ & \\
\hline $\mathrm{CU}$ & $18(178)$ & $18(178)$ & $18(178)$ & $24(184)$ & $48(208)$ & $48(208)$ \\
\hline EL & $0(144)$ & $0(144)$ & & & & \\
\hline GJ & $48(208)$ & $48(240)$ & $54(246)$ & 24 (184) & $24(220)$ & \\
\hline $\mathrm{KE}$ & $24(184)$ & $24(216)$ & $48(240)$ & $24(216)$ & $48(240)$ & \\
\hline MD & $48(240)$ & $48(240)$ & $42(234)$ & $108(220)$ & $48(240)$ & \\
\hline $\mathrm{MR}$ & $36(196)$ & 24 (184) & $48(240)$ & $24(184)$ & $48(208)$ & \\
\hline $\mathrm{NA}$ & $48(240)$ & 48 (184) & $72(264)$ & 24 (184) & $60(252)$ & \\
\hline $\mathrm{NE}$ & $24(184)$ & 24 (184) & $24(184)$ & $24(184)$ & 24 (184) & \\
\hline$P E$ & $18(178)$ & $60(252)$ & $48(208)$ & $48(208)$ & $48(240)$ & \\
\hline WO & $54(246)$ & $36(196)$ & $36(228)$ & $36(228)$ & $36(196)$ & \\
\hline $\mathrm{ZU}$ & $18(178)$ & 24 (184) & $24(184)$ & $24(216)$ & $24(184)$ & \\
\hline
\end{tabular}

diameter and $450 \mathrm{~mm}$ deep positioned at the centre of a $10 \mathrm{~m}$ long drift fence. In addition, 30 plastic 'tubs', $150 \times 150 \times 200 \mathrm{~mm}$ deep, were scattered across each quadrat during the Autumn (May 1995) survey. The tubs were sunk into the ground around the periphery of grass tussocks, and in the leaf litter under trees and shrubs.

Trapping effort is summarised in Table 1 , and a comprehensive breakdown of sampling effort by season is provided in Rolfe and McKenzie (2000). The quadrats were sampled for five days and nights in spring 1994 (27 September-20 October) and in late-autumn 1995 (9 May-8 June), a total of 80 fenced pitfall-trap nights per quadrat per seasonal visit. Further sampling was carried out on a sub-set of 29 quadrats in November 1995 (see 'Data

Table 3 Quadrats that had not yielded any Ctenophorus (C), Diplodactylus (D), Gehyra (G), small skinks such as a small Lerista (S), or large Lerista (L) species during the Spring 1994 and May 1995 sampling sessions (the first 10 days of sampling). Campsite locations are provided in Figure 1.

\begin{tabular}{lcccccc}
\hline Campsite & \multicolumn{7}{c}{ Quadrats } \\
& $\mathbf{1}$ & $\mathbf{2}$ & $\mathbf{3}$ & $\mathbf{4}$ & $\mathbf{5}$ & $\mathbf{6}$ \\
\hline BB & C & S & S & - & C & \\
BO & - & - & - & - & - & \\
CU & - & - & - & - & - & - \\
EL & - & - & & & & \\
GJ & - & - & - & - & G & \\
KE & - & D & CD & D & - & \\
MD & - & - & - & D & D & \\
MR & - & - & - & - & - & \\
NA & SD & - & - & - & C & \\
NE & - & L & CL & - & - & \\
PE & - & C & C & - & - & \\
WO & CD & - & C & - & - & \\
ZU & - & - & - & - & D \\
\hline
\end{tabular}

Quality', below), prior to a final resampling session at 61 of the quadrats in early-autumn 1996 (8-27 March) that involved an average of 44.8 fenced pitfall-trap nights per quadrat (see Table 2). When we compared our Spring 1994 collections with existing museum collections, a gap in the survey's coverage became evident, so two quadrats were belatedly established on Edel Land (EL), and first sampled in January 1995 (for 3-4 nights), then resampled for five nights during the Autumn 1995 fieldwork.

Reptiles and frogs were also caught in the five invertebrate pitfall traps ( $300 \times 400 \mathrm{~mm}$ buckets) set on each quadrat and left open for 12 months, a total of 114000 trap nights. Unlike the vertebrate buckets, each of these was partially filled with a solution of glycol-formalin (see Harvey et al., 2000), un-fenced, and covered by a sheet of wire mesh (10 mm square holes) designed to minimise accidental vertebrate deaths.

Approximately one person-hour per day per quadrat was spent foraging for herpetofauna during each sampling session, mainly by visual searching, stripping dead bark, turning logs, raking leaf litter, and digging. The staff involved all had prior experience in herpetofaunal surveys. We estimated that 702 person-hours were spent foraging for herpetofauna.

A representative collection of specimens, including frozen tissues, has been lodged in the Western Australian Museum. Species nomenclature in this report follows Aplin et al. (in press).

\section{Data Quality}

A sub-set of the quadrats was re-sampled in November. Using pitfall-trap arrays, but without the buckets, we re-sampled 23 of the 63 quadrats for two nights each (BB2, GJ2, GJ3, GJ5, KE2-5, MD1-5, MR3, NA1, NA3, NA5, PE2, PE5, WO1, 
WO3, WO4, ZU4). We also searched by hand for reptiles on 18 quadrats (BB1-3, BB5, GJ2, GJ3, GJ5, KE2-5, NA1, NA5, NE2, NE3, WO1, WO3 and WO4). These sub-sets included 18 of the 19 quadrats where there appeared to be 'gaps' in the expected community structure, i.e. widespread genera of dragons, skinks or geckoes had not been detected (e.g. Diplodactylus, Lerista or Ctenophorus - see Table 3). The possible outcomes were:

- if, on average, $<10 \%$ of the total lizard species recorded were new species-quadrat intersections, we would assume that the sampling was robust enough, unless some consistent pattern emerged or

- if $>10 \%$, were new, then we would re-sample all quadrats in March 1996.

As a result of the November 1995 assessment, further sampling was carried out at all quadrats (except for the two on Edel Land) in March 1996, with particular emphasis on those that had still yielded few if any reptiles (Table 2). The overall trapping effort by trap-type (except for the 150 tubnights /quadrat described in the previous section) is tabulated in McKenzie, Hall and Muir (2000); herein, these data are summarised in Table 1.

Species accumulation curves were used to assess the results of the sampling programme (both the trapping and the opportunistic searching). A curve was plotted for each of the 63 quadrats showing the increase in species-records per day during sampling. In compiling each curve, we excluded days when no frogs or reptiles at all were recorded from that quadrat (you have to encounter species for there to be a real opportunity to improve the quadrat's species list). This occurred if the weather was too cold for herpetofaunal activity and if handsearching effort was focussed on other quadrats. In effect, these were the days when there was no effective survey effort at the quadrat. Also, records derived from the invertebrate pits could not be included in the species accumulation curves because these traps were checked only five times during the year that they were open.

\section{Analysis of Patterns in Species Assemblages}

The analysis package PATN (Belbin, 1995) was used to seek patterns of species composition in the data matrices. The clustering techniques selected were described in McKenzie et al. (1991a). Briefly, the association measure 'Two-step' (Belbin, 1980) was used to determine the quantitative relationship between each pair of species, and the Czekanowski measure (Czekanowski, 1932) was used to compare the quadrats according to their species similarities. For both measures of association, a modified version of "unweighted pair group arithmetic averaging" (UPGMA - Sneath and Sokal, 1973; Belbin, 1995) hierarchial clustering strategy was used, with the clustering parameter (Beta) set to -0.1 .
The assemblages of reptiles and frog species recorded on the quadrats were used as the input data. We analysed the presence-absence of species on the quadrats, rather than their relative abundance, because limitations in sampling techniques, aggravated by staff and time limitations, precluded reliable abundance estimates (Austin, 1984; McKenzie et al., 1991b). The biological patterns revealed by these analyses were investigated in terms of a set of attributes related to the physical environment of the quadrats (see Wyrwoll, Courtney and Sandercock, 2000; Wyrwoll Stoneman, Elliott and Sandercock, 2000; Appendix $D$, this volume), and to the known habitat preferences of the species throughout their ranges elsewhere in Australia (Wilson and Knowles, 1988; Ehmann, 1992; Tyler et al., 1994). The generalised linear interactive modelling package GLIM (NAG, 1986; Nicholls, 1989) was used to model the relationships between the biological patterns and the physical attributes of the quadrats. Forward, stepwise regression models were fitted to each of the species-assemblages defined from the classification procedure, with quadrat speciesrichness used as the dependent variable. The significance of the parameters in the regression equations was calculated using the Wald Statistic, and is indicated by asterisks: $*<0.05,{ }^{* *}<0.01, * *<$ 0.001 , etc.

Eleven climatic attributes were derived for each quadrat using ANUCLIM (McMahon et al., 1995). Soil and geomorphic attributes were also recorded from each quadrat (Wyrwoll, Stoneman, Elliott and Sandercock, 2000). The 17 soil chemical and texture values used herein were derived from sub-samples collected from $20-30$ points on each quadrat at a depth of $5-10 \mathrm{~cm}$, then bulked (Appendix D). Significant inter-correlations between these physical attributes were identified using Kendall's rank correlation coefficient (Kendall's 'tau').

\section{Analysis of Patterns in Assemblages of Ecologically-defined Taxa}

Uneven phylogenetic discrimination can bias analyses of patterns in species composition. Speciescomplexes within Lerista, Diplodactylus and Ctenotus are distinguishable only on the basis of small differences in colour pattern and head-scale arrangement, and introduce strongly localised patterns of allopatry. Other congeneric species have much greater morphological differences, reflecting very different ecological roles.

To reduce the effect of uneven phylogenetic interpretation on the geographical analysis, we combined closely related taxa (usually congenerics) of similar potential foraging niche (Table 4). Factors such as shape, size, leg-length and usual foraging microhabitat, assigned to three or four categories each, were taken into account. Using this 'ecological 
Table 4 The species that were combined in terms of their functional morphology to provide an ecological taxonomy of the study area's herpetofauna. Species names differentiated by suffix letters (e.g. Lerista muelleriA and $L$. muelleriB) are yet to be described - see Aplin et al., in press)

Species

Combined Name

FROGS

Arenophryne rotunda, Psedophryne guentheri and Uperoleia russelli

PSEUDOPH

Neobatrachus aquilonius, $N$. sutor and N. wilsmorei

NEOBATRA

GECKOS

Diplodactylus alboguttatus and D. stenodactylus

Diplodactylus pulcher and D. klugei

Strophurus rankini, S. spinigerus and S. strophurus

Diplodactylus squarrosus and Rhynchoedura ornata

Gehyra punctata and G. variegata

PYGOPODIDS

Aprasia sp. aff. fusca, A. haroldi and A. smithi

Delma australis, D. butleri, D. nasuta, Pygopus nigriceps and Pygopus lepidopodus

DIPALBST

DIPPULKL

STROPH_1

DIP_RHYN

GEHYRA_

\section{DRAGONS}

Ctenophorus maculatus badius and C. m. maculatus

Ctenophorus femoralis and $C$. scutulatus

Ctenophorus nuchalis and C. reticulatus

Tympanocryptus parviceps and T. adelaidensis

APRASIA

$D E L \_P Y G O$

\section{SKINKS}

Cryptoblepharus carnabyi and C. plagiocephalus

Ctenotus alleni, C. australis, C. fallens, C. mimetes, $C$. saxatilis and $C$. severus

Ctenotus hanloniA, C. hanloniB and C. uber

Cyclodomorphus celatus, C. melanops melanops and Eremiascincus fasciolatus

Egernia depressa and E. stokesii badia

Lerista connivens, $L$. kendricki, L. petersoni and $L$. varia

Lerista planiventralis decora and L. p. planiventralis

Lerista elegans, L. haroldi, L. lineata, L. muelleriA - D

Lerista humphriesi, L. praepeditaA and L. praepeditaB

Lerista kennedyensis and L. uniduo

Lerista lineopunctulataA and L. macropisthopus

Menetia 'amaura', $M$. greyiA, $M$. greyi $\mathrm{B}$ and $M$. greyiC

Menetia surda cresswelli, $M$. surda subsp. indet. and Notoscincus ornatus ornatus

Morethia lineoocellata and M. obscura

Tiliqua multifasciata, T. occipitalis and T. rugosa

CTENOP_1

CTENOP_2

CTENOP_3

TYMPANOC

\section{GOANNAS}

Varanus brevicauda, $V$. caudolineatus and $V$. eremius

CRYPTOBL

CTENOT_1

CTENOT-2

CYC_ERE_

EGERNIA_

LERIST 1

LERIST_2

LERIST_3

LERIST_4

LERIST_5

LERIST 6

MENET 1

MENET_2

MORETH_2

TILIQUA_

VAR_SMAL

SNAKES

Demansia calodera and D. psammophis

SNAKE_S1

SNAKE_S2

SNAKE_L1

$S N A K E \_B L$

Pseudechis australis and Pseudonaja nuchalis

Ramphotyphlops australis, R. grypusA, R. grypusB and R. hamatus

SNAKE_S3

taxonomy', based on functional morphology, we compiled a new quadrat-versus-'ecological taxon' matrix to determine whether the same biogeographical and ecological relationships would emerge when the analyses were re-run using a matrix based on ecological taxa instead of species.

\section{RESULTS}

\section{Historical Review}

Prior to our field survey, 147 herpetofaunal species were known from the study area (Tables 5 and 6). We found $79 \%$ of these extant on our quadrats. Our quadrat-based sampling methods were more effective for dragons $(94 \%, 15$ of the previous list of 16 species), geckos $(85 \%, 17$ of 20$)$, goannas $(80 \%, 4$ of 5$)$, skinks $(79 \%, 44$ of 56$)$, and pygopodids (77\%, 10 of 13), than for frogs $(73 \%, 11$ of 15$)$ and snakes $(65 \%, 15$ of 23$)$.

\section{Data Quality}

If an asymptote is taken as three or more successive days with no new species captured, 47 of the 63 'species accumulation curves' had not reached an asymptote by the end of the Autumn 
Table 5 Frogs recorded in the study area prior to our survey (from Tyler et al., 1994). Quadrat locations are provided in Figure 1.

\begin{tabular}{|c|c|c|c|}
\hline Species & Range in W.A.* & 1994-6 Survey & Comments \\
\hline Arenophryne rotunda & $\begin{array}{l}\text { northern coastal GS, and } \\
\text { Dirk Hartog I. }\end{array}$ & EL1, ZU1-5 & \\
\hline Neobatrachus sutor & $\begin{array}{l}\text { coastal CAR but not west } \\
\text { of Lake MacLeod, YAL, } \\
\text { southern MUR }\end{array}$ & $\mathrm{BO} 4, \mathrm{BB} 5, \mathrm{MR} 1$ & \\
\hline N. pelobatoides & $\begin{array}{l}\text { South-west Province (incl. } \\
\text { GS), YAL, COO }\end{array}$ & ZU5 & \\
\hline N. wilsmorei & MUR, YAL, CAR & $\begin{array}{l}\mathrm{BB} 2,4, \mathrm{GJ} 2-5, \\
\mathrm{MD} 1,2,4,5, \text { WO5, } \\
\mathrm{ZU} 4,5\end{array}$ & closed gaps in western part of range \\
\hline$N$. fulvus & coastal CAR & $\mathrm{GJ} 2,3,5$ & $\begin{array}{l}\text { includes } N . \text { centralis and N. sp. (Gnarloo) } \\
\text { records from Storr and Harold }(1980,1990) \text {. }\end{array}$ \\
\hline N. aquilonius & $\begin{array}{l}\text { northern CAR, central } \\
\text { deserts }\end{array}$ & GJ2,5 & \\
\hline Notaden nichollsi & tropical arid & - & \\
\hline Pseudophryne guentheri & $\begin{array}{l}\text { South-west Province } \\
\text { (incl. GS) }\end{array}$ & MD3, ZU1 & range extension \\
\hline P. occidentalis & $\begin{array}{l}\text { COO, YAL, MUR, south } \\
\text { edge of CAR }\end{array}$ & - & \\
\hline Cyclorana maini & $\begin{array}{l}\text { CAR, eastern MUR, GAS, } \\
\text { PIL }\end{array}$ & $\begin{array}{l}\text { GJ2-5, MD3, } \\
\text { MR2,3 }\end{array}$ & closed gap in range \\
\hline C. platycephala & CAR, YAL, MUR, GAS & $\mathrm{MR} 2$ & $\begin{array}{l}\text { closed a gap in north-western } \\
\text { part of range }\end{array}$ \\
\hline Limnodynastes spenceri & $\begin{array}{l}\text { CAR, GAS, PIL, north } \\
\text { and east MUR }\end{array}$ & GJ1-5, MD3 & closed gap in range. \\
\hline Uperoleia russelli & CAR, PIL, north MUR & GJ1,5, MD3 & closed gap in range \\
\hline Liforia rubella & $\begin{array}{l}\text { CAR, GAS, PIL, north } \\
\text { MUR, Kimberley }\end{array}$ & GJ5, MD3 & closed gap in range \\
\hline Heleioporus albopunctatus & $\begin{array}{l}\text { South-west Province to } \\
27^{\circ} 30^{\prime} \mathrm{S}\end{array}$ & - & range limit is south of $\mathrm{ZU}$ \\
\hline Crinia pseudinsignifera & $\begin{array}{l}\text { South-west Province to } \\
27^{\circ} 30^{\prime} \text { S }\end{array}$ & - & range limit is south of $\mathrm{ZU}$ \\
\hline
\end{tabular}

* Geographical range in Western Australia is described in terms of IBRA Bioregions (Thackway and Cresswell, 1995): $\mathrm{GS}=$ Geraldton Sandplain, $\mathrm{CAR}=$ Carnarvon, $\mathrm{GAS}=$ Gascoyne, MUR = Murchison, $\mathrm{YAL}=\mathrm{Yalgoo}, \mathrm{COO}=$ Coolgardie and PIL = Pilbara.

1995 trapping programme (c. day 10 in Figure 2). Furthermore, the November 1995 ground-test of the field sampling detected a total of 89 species-records from the 29 quadrats that we re-sampled. Eighteen $(20 \%)$ of these were new species for their quadrats (Table 7), which exceeded the arbitrary $10 \%$ threshold (see Methods), so we re-sampled all quadrats in March 1996.

The results of the March 1996 session are summarised in Table 8 . While $62(24.9 \%)$ of the 249 species-records were new species for their quadrats, the hand-foraging component of our March sampling effort was biased towards perceived gaps in lizard community structure and the average improvement in the quadrat species lists was only $6 \%$ (from Tables 8 and 9), so we concluded that further field sampling effort would be costineffective. On the other hand, there is no doubt that our inventory of the quadrats was still incomplete: an additional species was detected on the last day of field effort at 23 of the 63 quadrats (Figure 2).

\section{Patterns in the Richness and Composition of Species Assemblages}

We found 133 species on our quadrats during the sampling program (Table 6): 12 frogs, 17 geckos, 10 pygopodids, 16 dragons, 58 skinks, four goannas and 16 snakes. This list includes a number of taxonomic sub-divisions of some of the species previously known from the study area, as well as three species recorded in the study area for the first time: Pseudophryne guentheri, $C$. calurus and Lerista lineata (see Tables 5 and 6, and Aplin et al., in press).

We recorded $16.3 \pm 5.6$ (s.d.) $(n=63)$ species on the average quadrat (Table 9). Quadrats on saline claypans were poorest in species (NA1, PE1, BB3 and CU1: $4.3 \pm 2.0,4)$, while those on red sand dunes were the richest (BB4, BO5, CU3, KE1, MR3, PE2 and PE5: $22.9 \pm 4.2,7$ ). Quadrats that had been regularly grazed by stock, feral goats and/or rabbits (BB, BO, CU, EL, GJ, KE3-5, MD, MR, NA1, NE2-5, $\mathrm{PE}, \mathrm{WO}$ and $\mathrm{ZU} 1-3: 16.1 \pm 5.9,54)$ were not significantly poorer in species than those that showed no sign of these introduced herbivores 

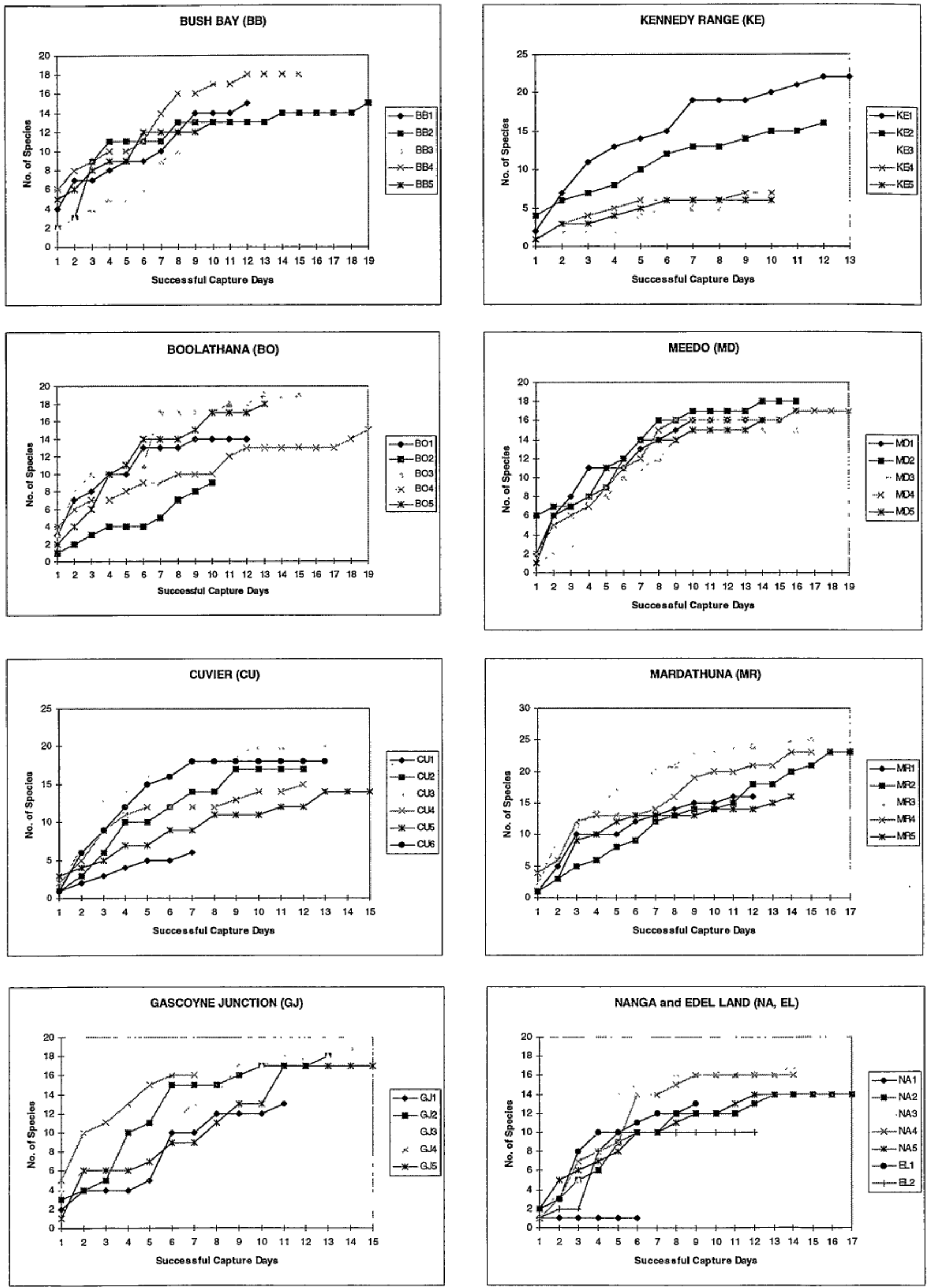

Figure 2 Accumulation of herpetofaunal species at each quadrat per day during the course of the trapping programme. We have excluded the days when no frogs or reptiles at all were recorded (see Methods). 
Table 6 Reptiles recorded in the study area (from Storr and Harold, 1980, 1984, 1990; Storr, 1991a,b,c; Kendrick, 1989, Western Australian Museum collection, and our field sampling program). $P=$ not recorded on quadrats during our 1994-6 survey. ${ }^{*}=$ Recorded during our survey, but not on quadrats. $N=$ new species-records for the study area from our quadrats. $T=$ new species or subspecies recognised during the course of the survey (also see Aplin et al., 2000).

\begin{tabular}{|c|c|c|c|c|c|}
\hline GECKOS & & SKINKS & & L. praepeditaA & $\mathbf{T}$ \\
\hline Christinus marmoratus & $\mathbf{P}$ & Cryptoblepharus & & L. praepeditaB & $\mathbf{T}$ \\
\hline Crenadactylus sp. aff. ocellatus & $\mathbf{T}$ & carnabyi (A and B) & $\mathbf{T}$ & L. uniduo & \\
\hline Diplodactylus alboguttatus & & C. plagiocephalus & & L. varia & \\
\hline D. conspicillatus & & Ctenotus alleni & & Menetia 'amaura' & \\
\hline D. klugei & $\mathbf{T}$ & C. calurus & $\mathbf{N}$ & M. greyiiA & $\mathbf{T}$ \\
\hline D. ornatus & & C. fallens & & M. greyii $\mathrm{B}$ & $\mathrm{T}$ \\
\hline D. pulcher & & C. hanloniA & $\mathrm{T}$ & M. greyiiC & $\mathbf{T}$ \\
\hline D. squarrosus & & C. hanloniB & $\mathbf{T}$ & M. surda cresswelli & $\mathrm{T}$ \\
\hline D. stenodactylus & & C. iapetus & & M. surda subsp. indet. & $\mathbf{T}$ \\
\hline Strophurus michaelseni & $\mathbf{P}$ & C. leonhardii & $\mathbf{P}$ & Morethia butleri & \\
\hline S. rankini & & C. australis & & M. lineoocellata & \\
\hline S. spinigerus & & C. mimetes & & M. obscura & \\
\hline S. strophurus & & C. pantherinus & & M. ruficauda exquisita & \\
\hline Gehyra punctata & & C. piankai & $\mathbf{N}$ & Notoscincus ornatus ornatus & \\
\hline G. variegata & & C. nufescens & & Tiliqua multifasciata & \\
\hline Heteronotia binoei & & C. saxatilis & & T. occipitalis & \\
\hline H. spelea & & C. schomburgkii & & T. rugosa & \\
\hline Nephrurus levis & & C. severus & & & \\
\hline Rhynchoedura ornata & & C. uber & & GOANNAS & \\
\hline Underwoodisaurus milii & $\mathbf{P}$ & C. youngsoni & $\mathbf{P}$ & Varanus brevicauda & \\
\hline PYGOPODIDS & & C. zastictus & $\mathbf{P}$ & $\begin{array}{l}\text { V. caudolineatus } \\
\text { V.eremius }\end{array}$ & \\
\hline Aclys concinna major & $\mathbf{P}^{*}$ & Cyclodomorphus celatus & & & \\
\hline Aprasia sp. aff. fusca & $\mathbf{T}$ & $\begin{array}{l}\text { C. melanops melanops } \\
\text { Egernia multiscutata bos }\end{array}$ & $\mathbf{P}$ & $V \cdot$ giganteus & $\mathbf{P}^{*}$ \\
\hline A. haroldi & & E. depressa & & SNAKES & \\
\hline A. smithi & & E. inornata & $\mathbf{P}$ & Acanthophis pyrrhus & \\
\hline Delma australis & & E. kingii & $\mathbf{P}$ & Aspidites ramsayi & $\mathbf{P}$ \\
\hline D. butleri & & E. stokesii stokesii & $\mathbf{P}$ & Demansia calodera & \\
\hline D. nasuta & & E. stokesii badia & & D. psammophis & \\
\hline D. fraseri & $\mathbf{P}$ & Eremiascincus fasciolatus & & Suta fasciata & \\
\hline D. tincta & $\mathbf{P}$ & E. richardsonii & $\mathbf{P}$ & Parasuta monarchus & $\mathbf{p}$ \\
\hline Lialis burtonis & & Lerista bipes & & Furina ornata & \\
\hline Pletholax gracilis edelensis & & L. connivens & & Antaresia perthensis & \\
\hline Pygopus lepidopodus & & L. elegans & & A. stimsoni stimsoni & $\mathbf{P}^{*}$ \\
\hline$P$. nigriceps & & L. gascoynensis & & Pseudechis australis & \\
\hline DRAGONS & & L. haroldi & & Pseudonaja modesta & \\
\hline Amphibolurus longirostris & & L. humphriesi & & P. nuchalis & \\
\hline Ctenophorus caudicinctus & & L. kendricki & & Ramphotyphlops australis & \\
\hline C. clayi & & L. kennedyensis & & R. grypusA & $\mathbf{T}$ \\
\hline C. femoralis & & L. lineata & $\mathbf{N}$ & R. grypus B & $\mathbf{T}$ \\
\hline C. maculatus badius & & L. lineopunctulataA & & $R$. hamatus & \\
\hline C. m. maculatus & & L. macropisthopus & & R. leptosoma & $\mathbf{P}$ \\
\hline C. nuchalis & & L. muelleriA & $\mathbf{T}$ & R. waitii & $\mathbf{P}$ \\
\hline C. reticulatus & & L. muelleriB & $\mathbf{T}$ & Brachyurophis approximans & $\mathbf{P}$ \\
\hline C. rubens A and B & $\mathbf{T}$ & L. muelleriC & $\mathbf{T}$ & B. fasciolata fasciolata & $\mathbf{P}$ \\
\hline C. scutulatus & & L. muelleriD & $\mathbf{T}$ & B. semifasciatus & $\mathbf{P}$ \\
\hline Diporiphora winneckei & & L. petersoni & & Neelaps bimaculata & \\
\hline Moloch horridus & & L. planiventralis decora & & Simoselaps bertholdi & \\
\hline Pogona minor & & L.p. planiventralis & & S. littoralis & \\
\hline Rankinia a adelaidensis & & & & & \\
\hline Tympanocryptis parviceps & & & & & \\
\hline T. butleri & $\mathbf{P}$ & & & & \\
\hline
\end{tabular}

In Figure 3, the 63 quadrats have been re-ordered in terms of similarities in their species composition. The sorting strategy yielded a quadrat-dendrogram that summarised the herpetofaunal patterns of occurrence (Figure 4).

Several distinct step-wise structures dominate both the quadrat- and the species-dendrograms. Such structures would occur if the speciesassemblages were responding to different gradients in the physical environment or differently to sub-sets of environmental gradients (McKenzie et al., 1989, 1991a). To test this 
Table 7 Number of herpetofaunal species recorded during the November 1995 sampling session / number of species that were new records for the quadrat. Campsite locations are provided in Figure 1.

\begin{tabular}{lllllll}
\hline Campsite & \multicolumn{6}{c}{ Quadrat } \\
& $\mathbf{1}$ & $\mathbf{2}$ & $\mathbf{3}$ & $\mathbf{4}$ & $\mathbf{5}$ & $\mathbf{6}$ \\
\hline BB & $2 / 2$ & $5 / 1$ & $0 / 0$ & - & $0 / 0$ & \\
BO & - & - & - & - & - & \\
CU & - & - & - & - & - & - \\
EL & - & - & & & & \\
GJ & - & $3 / 0$ & $3 / 0$ & - & $10 / 5$ & \\
KE & - & $5 / 1$ & $2 / 0$ & $3 / 1$ & $0 / 0$ & \\
MD & $7 / 0$ & $6 / 0$ & $3 / 0$ & $6 / 0$ & $5 / 1$ & \\
MR & - & - & $3 / 0$ & - & - & \\
NA & $1 / 0$ & $1 / 1$ & $2 / 0$ & - & $4 / 2$ & \\
NE & - & $1 / 0$ & $6 / 3$ & - & - & \\
PE & - & $0 / 0$ & - & - & $0 / 0$ & \\
WO & $3 / 0$ & - & $4 / 0$ & $1 / 0$ & - & \\
ZU & - & - & - & $3 / 1$ & -
\end{tabular}

hypothesis, the four species-assemblages were treated as independent data-sets and analysed separately using the above analysis pathways and the package GLIM. GLIM was used to model assemblage species richness in terms of the physical attributes of the quadrats.

Assemblage-1's species richness at quadrats (Figure 3) was best explained in terms of precipitation in the warmest quarter (Pwar), soil potassium $\left(\mathrm{KHCO}_{3}\right)$ and altitude (ALT) using the equation:

Ln (species richness) $=-3.695+0.0008$ Pwar $^{2}-0.014$ $\mathrm{KHCO}_{3}+0.007 \mathrm{ALT}$

Standard error (s.e.) $=0.682^{* * *}$ for the constant (the $y$-intercept), $0.0001^{* * *}$ for Pwar $^{2}, 0.004^{* *}$ for $\mathrm{KHCO}_{3}$ and $0.001^{* * * *}$ for ALT, respectively (significance indicated by asterisks).

Scaled deviance $=43$, d.f. $=59$

Scaled deviance of null model $=306$, d.f. $=62$

Scaled deviance for Pwar $^{2}=137$, d.f. $=61$

Scaled deviance for $\mathrm{Pwar}^{2}+\mathrm{KHCO}_{3}=73$, d.f. $=60$

The model was sensitive to quadrat MR1, so the model was re-fitted with this data-point deleted (weighted to zero):

Ln (species richness) $=-3.945+0.0008$ Pwar $^{2}-0.012$ $\mathrm{KHCO}_{3}+0.007$ ALT

s.e. $=0.735^{* * * *}$ for the constant, $0.0001^{* * * *}$ for Pwar' ${ }^{2}$, $0.004^{* *}$ for $\mathrm{KHCO}_{3}$ and $0.001^{* * * *}$ for ALT, respectively. Scaled deviance $=40$, d.f. $=58$

Since there was hardly any change in the terms of the re-fitted model, the first model was considered to be satisfactory.

In Figure 5, the 63 quadrats have been classified in terms of species belonging to assemblage-1 (from Figure 3), so that the assemblage's pattern of occurrence across the study area could be summarised as a dendrogram. Univariate data on aspects of the quadrat's physical environments were superimposed as a histogram on this dendrogram, attribute-by-attribute. This iterative process allowed us to identify the physical attributes that most closely conformed to the patterns in assemblage-1's species-composition across the study area. Assemblage-1's dendrogram structure (Figure 5) showed a significant fit to the gradient in summer rainfall (Pwar: Kruskall Wallis $\mathrm{H}=15.3$, p. $=0.0005$ at the 3-group level) and, within that, to altitude (ALT: $\mathrm{H}=12.4$, p. $=0.002$ at the 3-group level) and soil potassium ( $\mathrm{KHCO}_{3}: \mathrm{H}=$ 6.8, separated group-5 from group-4 and group-6). Altitude and soil potassium were only relevant in the context of environments with high summer rainfall (Pwar). These are found at the north end of the study area, which explains the inter-correlations with latitude (LAT) and certain temperature attributes (see Table 10).

Assemblage-2's species richness at quadrats was best explained in terms of precipitation seasonality (Psea), soil potassium and longitude (LONG) using the equation:

Ln (species richness) $=80.8+0.572$ Psea -0.003 Psea $^{2}-0.009 \mathrm{KHCO}_{3}-0.933 \mathrm{LONG}$

s.e. $=27.4^{* * *}$ for the constant, $0.182^{* *}$ for Psea, $0.001^{* *}$ for $\mathrm{Psea}^{2}, 0.001$ for $\mathrm{KHCO}_{3}^{* * * *}$ and $0.203^{* * * *}$ for LONG, respectively.

Scaled deviance $=71$, d.f. $=58$

Scaled deviance for null model $=411$, d.f. $=62$

Scaled deviance for Psea $=175$, d.f. $=61$

Scaled deviance for Psea $+\mathrm{Psea}^{2}=153$, d.f. $=60$

Scaled deviance for Psea $+\mathrm{Psea}^{2}+\mathrm{KHCO}_{3}=93$, d.f. $=59$

The model was sensitive to CU6 and ZU3, but as there was hardly any change in the model parameters when it was re-fitted with these data points deleted (see below), the original model was considered to be satisfactory.

Table 8 Number of herpetofaunal species recorded during the March 1996 sampling session / number of species that were new records for the quadrat. Campsite locations are provided in Figure 1.

\begin{tabular}{lcclccc}
\hline Campsite & \multicolumn{5}{c}{ Quadrat } \\
& $\mathbf{1}$ & $\mathbf{2}$ & $\mathbf{3}$ & $\mathbf{4}$ & $\mathbf{5}$ & $\mathbf{6}$ \\
\hline $\mathrm{BB}$ & $4 / 1$ & $3 / 1$ & $1 / 0$ & $9 / 1$ & $5 / 1$ & \\
$\mathrm{BO}$ & $3 / 0$ & $3 / 2$ & $12 / 2$ & $10 / 5$ & $5 / 1$ & \\
$\mathrm{CU}$ & $3 / 1$ & $7 / 0$ & $3 / 0$ & $4 / 1$ & $7 / 2$ & $6 / 0$ \\
$\mathrm{EL}$ & - & - & & & & \\
$\mathrm{GJ}$ & $3 / 1$ & $5 / 2$ & $6 / 1$ & $3 / 1$ & $3 / 0$ & \\
$\mathrm{KE}$ & $5 / 1$ & $1 / 1$ & $1 / 0$ & $2 / 0$ & $3 / 0$ & \\
$\mathrm{MD}$ & $8 / 1$ & $9 / 2$ & $3 / 0$ & $8 / 1$ & $4 / 1$ & \\
$\mathrm{MR}$ & $5 / 1$ & $7 / 5$ & $9 / 1$ & $8 / 2$ & $7 / 2$ & \\
NA & $0 / 0$ & $3 / 0$ & $5 / 2$ & $2 / 0$ & $1 / 0$ & \\
NE & $1 / 1$ & $2 / 1$ & $1 / 0$ & $0 / 0$ & $3 / 1$ & \\
$\mathrm{PE}$ & $0 / 0$ & $6 / 0$ & $2 / 1$ & $2 / 0$ & $4 / 2$ & \\
WO & $7 / 1$ & $7 / 4$ & $3 / 2$ & $3 / 1$ & $7 / 4$ & \\
ZU & $1 / 0$ & $0 / 0$ & $2 / 1$ & $2 / 0$ & $0 / 0$ & \\
\hline
\end{tabular}


Figure 3 Entire data matrix re-ordered according to species co-occurrences at the same quadrats and similarities in the overall species composition of the quadrats. Quadrat codes are printed vertically. Species dendrogram is included to indicate classification structure down to the 9 group level.

QUADRAT CODES

BMMWWWMMMWWNNNNNBBBB GMGGGG KKMMMM BCN P KKK BBBNNNNNCCCCCPPPP EEZZZZZ

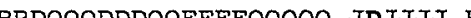

\section{ASSEMBLAGE-1}

$115213124541534134521323541225343111^{1345245223452345623541221345}$

canthophis pyrrhus.........

Lerista aff. muelleric..........

Ctenotus saxatilis.

Diporiphora winneckei........

Notoscincus ornatus.ornatus...

Lerista kennedyensis.........

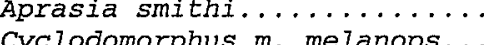

Cyclodomorphus m. melanops...

Ctenophorus femoralis...

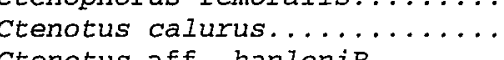

f. hanloniB.

Ctenotus pantherinus.

tenophorus rubens..

Ctenophorus clayi.....

Menetia surda cresswelli......

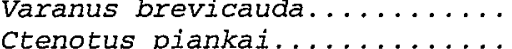

Ctenotus piankai...

Menetia aff. greyiic..........

Lerista bipes.

Cyclorana platycephalus.......

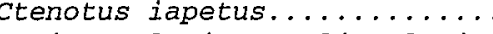

Lerista planiventralis plani.

ASSEMBLAGE-2

Aprasia sp aff. fusca........

Lerista haroldi.

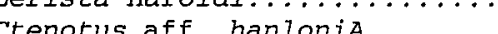

Clenotus ate. hanlonia.........

Menetia aff greyiis.

Pseudonaja nuchalis.

Demansia psammophis..

Delma nasuta.

trophurus michael...........

seudechis australis.

Crenadactylus aff. ocellatus.

Ctenotus alleni.

Menetia surda subso indet....

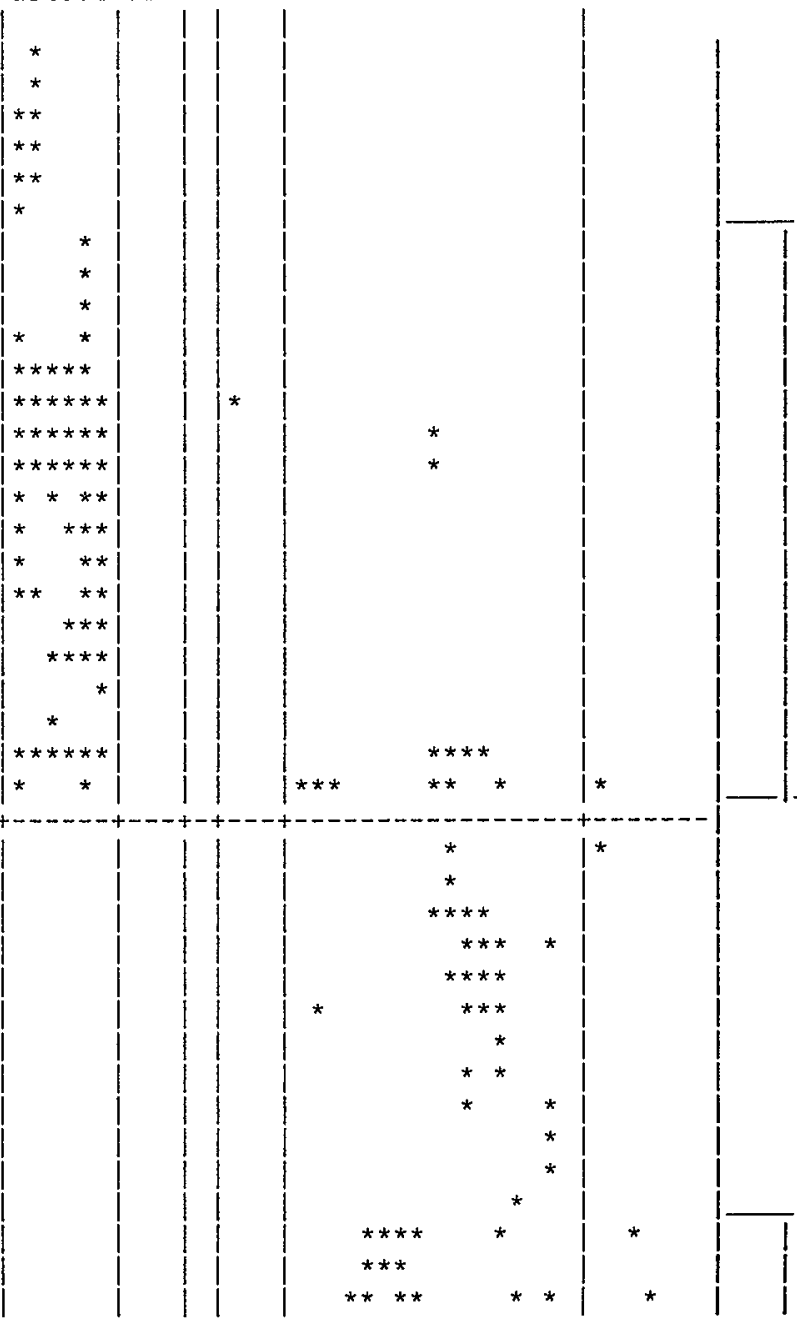


Lerethia lineoocellata...

Lerista lineopunctulata...

Menetia 'amaura'.

Ctenotus fallens.

cyclodomorphus celatus.

Simoselaps littoralis...

Lerista aff. praepeditaB.

Lerista varia..

Tiliqua rugosa.

Lialis burtonis.

Aprasia haroldi.

Arenophryne rotunda...

strophurus spinigerus. .

Atrophurus spinigerus.........

Pletholax gracilis edelensis..

Tympanocryptis parvicep.

Pygopus lepiaopodus..........

Neelaps bimaculata.

Cryptoblepharus carnaby

Ctenotus australis.

Cenophorus maculatus maculat.

Lerista planiventralis decora.

Lerista kendricki. .

Neobatrachus pelobatoides....

ASSEMBLAGE-3

Cryptoblepharus plagiocephalus

Suta fasciata.

Diplodactylus klugei.

Egernia depressa.

Furina ornata.

Morethia butleri.

Morethia obscura.

Ctenotus uber.

Lerista petersoni. . .

Lerista aff. muellexid.

Ctenotus mimetes.

Tiliqua occipitali.

Neobatrachus sutor.

Lerista lineata. .

Tiliqua multifasciata.

Egernia stokesii badia.

Amphibolurus longirostris.......

Pseudophryme guentheri..

$\mid * * * * * * * * * * 1 * *$

$*$

$* \star * * * \mid \begin{aligned} & * \star * * * \\ & * * * *\end{aligned}$

$* * * * * * *$ | $* * *$

$\star * * * * \quad * * * *+* * * *$

$* * * *$

* $* * * *$

* $\quad * * * \mid * *$

$\star \quad * * * * * \mid *$

$* x * * * x \mid$
$* * * * \mid$

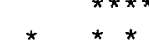

*

*

|***

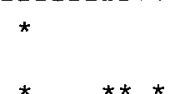
$* *$
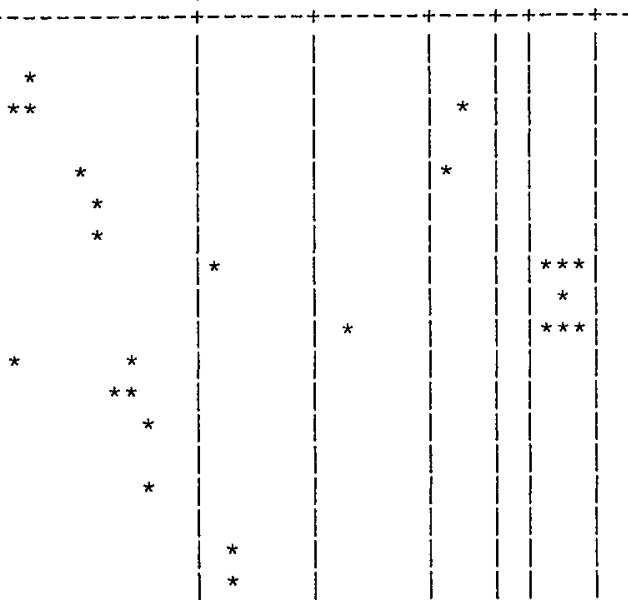

**

$*$ 


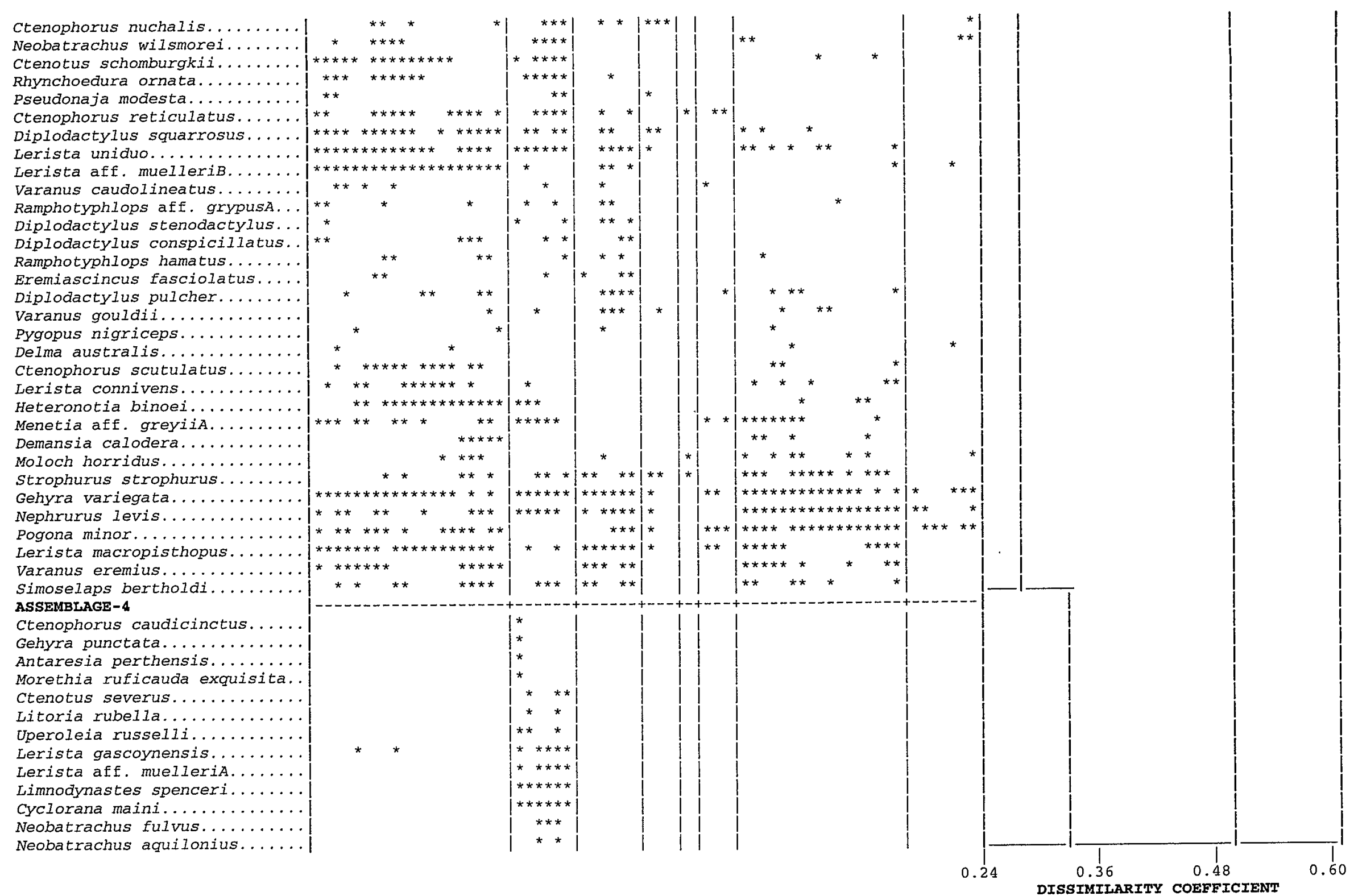


Table 9 Herpetofaunal species richness per quadrat. Campsite locations are provided in Figure 1.

\begin{tabular}{lllllll}
\hline Campsite & \multicolumn{6}{c}{ Quadrat } \\
& $\mathbf{1}$ & $\mathbf{2}$ & $\mathbf{3}$ & $\mathbf{4}$ & $\mathbf{5}$ & $\mathbf{6}$ \\
\hline BB & 16 & 16 & $6^{*}$ & 19 & 15 & \\
BO & 14 & 10 & 22 & 18 & 18 & \\
CU & 6 & 18 & 23 & 16 & 17 & 23 \\
EL & 15 & 10 & - & - & - & \\
GJ & 17 & 20 & 19 & 18 & 23 & \\
KE & 22 & 18 & 8 & 7 & 6 & \\
MD & 17 & 20 & 18 & 17 & 17 & \\
MR & 18 & 28 & 31 & 26 & 20 & \\
NA & 1 & 15 & 20 & 19 & 16 & \\
NE & 17 & 14 & 13 & 16 & 11 & \\
PE & 4 & 22 & 18 & 19 & 24 & \\
WO & 13 & 14 & 14 & 13 & 18 & \\
ZU & 16 & 12 & 22 & 13 & 14 & \\
\hline
\end{tabular}

* 11 if sandy patch species are included.

Ln (species richness) $=82.5+0.585$ Psea -0.003 $\mathrm{Psea}^{2}-0.008 \mathrm{KHCO}_{3}-0.95 \mathrm{LONG}$

s.e. $=30.6^{* *}$ for the constant, $0.187^{* *}$ for Psea, $0.001^{* *}$ for $\mathrm{Psea}^{2}, 0.002^{* * * *}$ for $\mathrm{KHCO}_{3}$ and $0.23^{* * * *}$ for LONG, respectively. Scaled deviance $=59$, d.f. $=56$

Assemblage-2's compositional structure (Figure 3) conformed with a precipitation seasonality gradient across sandy quadrats (low in potassium) of the temperate and/or coastal (low Longitude) parts of the study area (Figure 6). At the 7-group level, Psea had a Kruskall Wallis $\mathrm{H}$ of 38.7 (p. $<0.0000$ ) and $\mathrm{KHCO}_{3}$ had an $\mathrm{H}$ of 31.6 (p. $<0.0000$ ), while LONG had an $\mathrm{H}$ of 34.6 (p. $<0.0003$ ) at the 12-group level. The seasonality gradient was strongly intercorrelated with some other climatic attributes (Table 11). Patterns of allopatry among Strophurus, Tympanocryptus and Lerista were not reflected by the histograms.

Assemblage-3's species richness at quadrats was best explained in terms of annual average precipitation (Pann), soil electrical conductivity (EC) and altitude (ALT) using the equation:

Ln (species richness) $=5.827-0.014$ Pann - 0.001 EC - 0.0015 ALT

Table 10 Kruskall-Wallis values for the intercorrelated physical attributes that showed significant $(<0.05)$ differences between groups of assemblage-1 quadrats that had been clustered in terms of their species similarities (Figure 5).

\begin{tabular}{lcc}
\hline Attribute & $\begin{array}{r}\text { Kruskal-Wallis } \\
\text { value at } \\
\text { 3 groups }\end{array}$ & $\begin{array}{c}\text { Kendall's Tau } \\
\text { (prob.) from } \\
\text { Appendix 1 }\end{array}$ \\
\hline Warmest Quarter Precipitation & 15 & \\
Latitude & 18 & $-0.73\left(\left(^{* * * *}\right)\right.$ \\
Wettest Quarter Temperature & 18 & $0.59\left(^{* * * *)}\right.$ \\
Annual Average Temperature & 17 & $0.73\left(^{* * * *}\right)$ \\
Warmest Quarter Temperature & 14 & $0.60\left(^{* * * *}\right)$ \\
\hline
\end{tabular}

s.e. $=0.387^{* * * *}$ for the constant, $0.002^{* * * *}$ for Pann, $0.0003^{* *}$ for EC and $0.0005^{* *}$ for ALT, respectively

Scaled deviance $=59.4$, d.f. $=59$

Scaled deviance for null model $=177.7$, d.f. $=62$

Scaled deviance for Pann $=83.6$, d.f. $=61$

Scaled deviance for Pann $+\mathrm{EC}=67.8$, d.f. $=60$

The model was sensitive to the saline playa quadrats PE1 and NA1. When these were weighted to zero, and the model re-fitted, EC was no longer significant, but the coefficients of the $y$-intercept and Pann barely changed (see below), so the original model was considered to be satisfactory.

Ln (species richness) $=5.83-0.014$ Pann -0.0013 ALT

s.e. $=0.39^{* * * *}$ for the constant, $0.002^{* * * *}$ for Pann and $0.0005^{* *}$ for ALT. Scaled deviance $=59$, d.f. $=$ 58

Assemblage-3's species composition (Figure 3) conformed with an annual average precipitation gradient across non-saline soils at low altitude (Figure 7). At the 9-group level, the Kruskall Wallis $\mathrm{H}$ for Pann was 42.1 (p. $<0.0000$ ), for ALT was 33.5 (p. < 0.0000) and for EC was 13.7 (p. = 0.09). Annual rainfall was strongly correlated with some other climatic attributes (Table 12). There were several distinct mis-matches between the observed gradient in species composition and the climatic values at quadrats such as KE1-2 and MR2-4 (Figure 7). The displaced allopatric cluster comprising Ctenotus uber, Lerista petersoni and Lerista muelleriD at KE3-5, is visible in the shape of the annual precipitation (Pann) histogram (group-7 in Figure 7). Species associated with a small sandy rise on quadrat BB3 have been removed from the analysis because the soil sample came from the samphire.

Assemblage-4 (Figure 3) only occurred in areas subject to unchannelled over-bank stream-flow (gs_over, Figure 8), a geomorphic process associated with riverine flood plains (Wyrwoll,

Table 11 Kruskall-Wallis values for intercorrelated physical attributes that showed significant $(<0.05)$ differences between groups of assemblage-2 quadrats that had been clustered in terms of their herpetofaunal similarities (Figure 6).

\begin{tabular}{lcc}
\hline Attribute & $\begin{array}{c}\text { Kruskal-Wallis } \\
\text { value at } \\
\text { 7-groups }\end{array}$ & $\begin{array}{c}\text { Kendall's Tau } \\
\text { (prob.) from } \\
\text { Appendix 1 }\end{array}$ \\
\hline Precipitation Seasonality & 39 & \\
Wettest Quarter Precipitation & 43 & $0.81\left(^{* * *}\right)$ \\
Coldest Quarter Precipitation & 41 & $0.81\left(^{* * *}\right)$ \\
Annual Average Precipitation & 43 & $0.74\left(^{* * *}\right)$ \\
Warmest Quarter Precipitation & 17 & $0.81\left(^{* * *}\right)$ \\
Warmest Quarter Temperature & 34 & $-0.77\left(^{* * *}\right)$ \\
Annual Average Temperature & 23 & $-0.53\left(^{* * *}\right)$ \\
soil potassium $\left(\mathrm{KHCO}_{3}\right)$ & 32 & $-0.26\left(^{* *}\right)$ \\
Longitude & 23 & $-0.57\left(^{* * *}\right)$ \\
\hline
\end{tabular}


Stoneman, Elliott and Sandercock, 2000). The four singleton species are rock-scree dwellers; their presence on GJ1 is an ecotonal effect and was discussed earlier. No model was developed for this assemblage because its species occur at only eight quadrats, because of the ecotonal affect of GJ1, and because 'gs_over' was ordinal data with only four categories.

\section{Analysis of Patterns in Assemblages of Ecologically-defined Taxa}

To minimise the influence of phylogeny on the geographical analysis, we re-analysed the quadrat data using an ecological taxonomy that was based on functional morphology (Table 4). Classification of the 68 ecological taxa according to similarities in their co-occurrences at the same quadrats yielded similar assemblage boundaries to those derived from the species analysis (Figure 9):

- Assemblage-1: Taxa characteristically restricted to hummock grass communities on the red sandplains and dune fields of the arid zone, with ranges extending across middle and tropical latitudes.

- Assemblage-2: Taxa of semi-arid to arid temperate areas of the west coast and southern

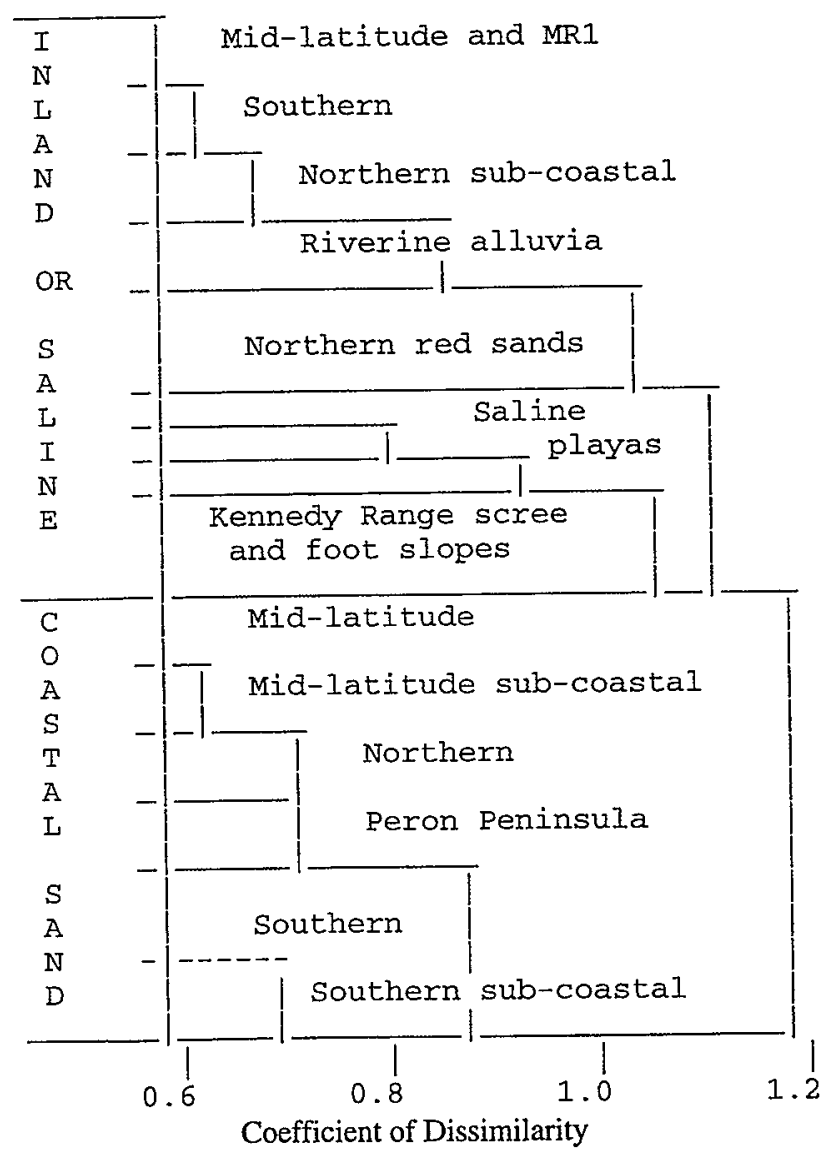

Figure 4 Quadrats classified according to similarities in their species composition. Dendrogram structure to the 15-group level is displayed.
Table 12 Kruskall-Wallis values for intercorrelated physical attributes that showed significant $(<0.05)$ differences between groups of assemblage- 3 quadrats that had been clustered in terms of their herpetofaunal similarities (Figure 7).

\begin{tabular}{lcc}
\hline Attribute & $\begin{array}{c}\text { Kruskal-Wallis } \\
\text { value at } \\
\text { 9 groups }\end{array}$ & $\begin{array}{c}\text { Kendall's Tau } \\
\text { (prob.) from } \\
\text { Appendix 1. }\end{array}$ \\
\hline Annual Average Precipitation & 42 & \\
Wettest Quarter Precipitation & 38 & $0.74\left(^{* * *}\right)$ \\
Coldest Quarter Precipitation & 37 & $0.71\left(^{* * *}\right)$ \\
Warmest Quarter Temperature & 34 & $-0.61\left(^{* * *}\right)$ \\
\hline
\end{tabular}

half of Australia, that favour the variety of sandy surfaces (hummock grasslands and shrublands). Some taxa are confined to this coastal strip.

- Assemblage-3: Widespread arid to semi-arid taxa, many of which are confined to finer textured soils, from loamy-sands and sandyloams to alluvial plains and even samphire pans.

- Assemblage-4 had two components: (1) singleton taxa normally associated with rock surfaces (Ctenophorus caudicinctus, Antaresia perthensis and Morethia ruficauda exquisita) were previously included in Assemblage-4 (Figure 3) because of the ecotonal position of the quadrat GJ1: low on the scree slope of the Pell range, 0.1 $\mathrm{km}$ from the floodways and levee banks of the Gascoyne River; (2) species restricted to riverine flood plains. In Figure 3, these were included in Assemblage-4.

- Six assemblages comprising one or two taxa that were recorded on only one or two quadrats.

Of the nine assemblages defined in Figure 9, only four involved sufficient taxa and quadrats to analyse. In Figure 9 they are labelled according to the assemblage they most closely resemble in Figure 3. As previously, the four assemblages were treated as independent data-sets and the package GLIM was used to model the assemblage's species richness in terms of the physical attributes of the quadrats.

Assemblage-1's species richness at quadrats was best explained by the equation:

Ln (species richness) $=-3.04+0.0007 \mathrm{Pwar}^{2}-0.008$ $\mathrm{KHCO}_{3}+0.004 \mathrm{ALT}$

s.e. $=0.58^{* * * *}$ for the constant (the $y$-intercept), $0.0001^{* * * *}$ for $\mathrm{Pwar}^{2}, 0.002^{* * * *}$ for $\mathrm{KHCO}_{3}$ and $0.001^{* * *}$ for ALT. Asterisks indicate parameter significance. Scaled deviance $=50$, d.f. $=59$; scaled deviance of null model $=306$, d.f. $=62$. The model was sensitive to quadrat MR1, which was poorer in species than predicted.

Assemblage-2's species richness at quadrats was best explained by the equation:

Ln (species richness) $=-2.45+0.047$ Psea -0.005 $\mathrm{KHCO}_{3}$ 
s.e. $=0.71^{* * * *}$ for the constant, $0.008^{* * * *}$ for Psea and $0.001^{* * * *}$ for $\mathrm{KHCO}_{3}$. Scaled deviance $=74$, d.f. $=60$; scaled deviance of null model $=411$, d.f. $=62$. The model was sensitive to the saline playa quadrats PE1 and NA1.

Assemblage-3's species richness at quadrats was best explained by the equation:

Ln (species richness) $=3.97-0.006$ Pann $-0.001 \mathrm{EC}-$ 0.0018 ALT

s.e. $=0.34^{* * * *}$ for the constant, $0.001^{* * * *}$ for Pann, $0.0003^{* *}$ for EC and $0.0005^{* * *}$ for ALT. Scaled deviance $=40$, d.f. $=59$; scaled deviance of null model $=178$, d.f. $=62$. The model was sensitive to quadrats PE1 and NA1.

Assemblage- 4 taxa occurred at too few quadrats to model. They only occurred in areas subject to unchannelled over-bank stream-flow (gs_over), consistent with the equivalent assemblage in Figure 3. The three singleton taxa are the rock-scree dwellers discussed earlier.

In each case, the best linear predictors were the same as those identified for the equivalent speciesbased assemblage. The only exception was 'longitude' (LONG) in the assemblage-2 equation.

\section{DISCUSSION}

\section{Extant Fauna}

Sixteen frog and 146 reptile taxa are now known from the study area, although 19 of the reptiles are yet to be described (see Aplin et al., in press). We found no evidence of introduced reptile or amphibian species.

While only three species were recorded in the study area for the first time, the species-level variation identified within our collections provides some measure of the geographically biased nature of previous reptile surveys in the area. Eleven of the previously known species have been sub-divided (see Aplin et al. in press), so that 22 'new' taxa are listed in Table 6.

Many of the 25 species we did not encounter (Tables 5 and 6) have geographic ranges that are centred on other regions and occur only on the margins of our study area (e.g. Heleioporus albopunctatus, Crinia pseudinsignifera, Underwoodisaurus milii, Tympanocryptis butleri and Ctenotus youngsoni). Others are strongly localised (e.g. Ctenotus zastictus) or confined to the islands in

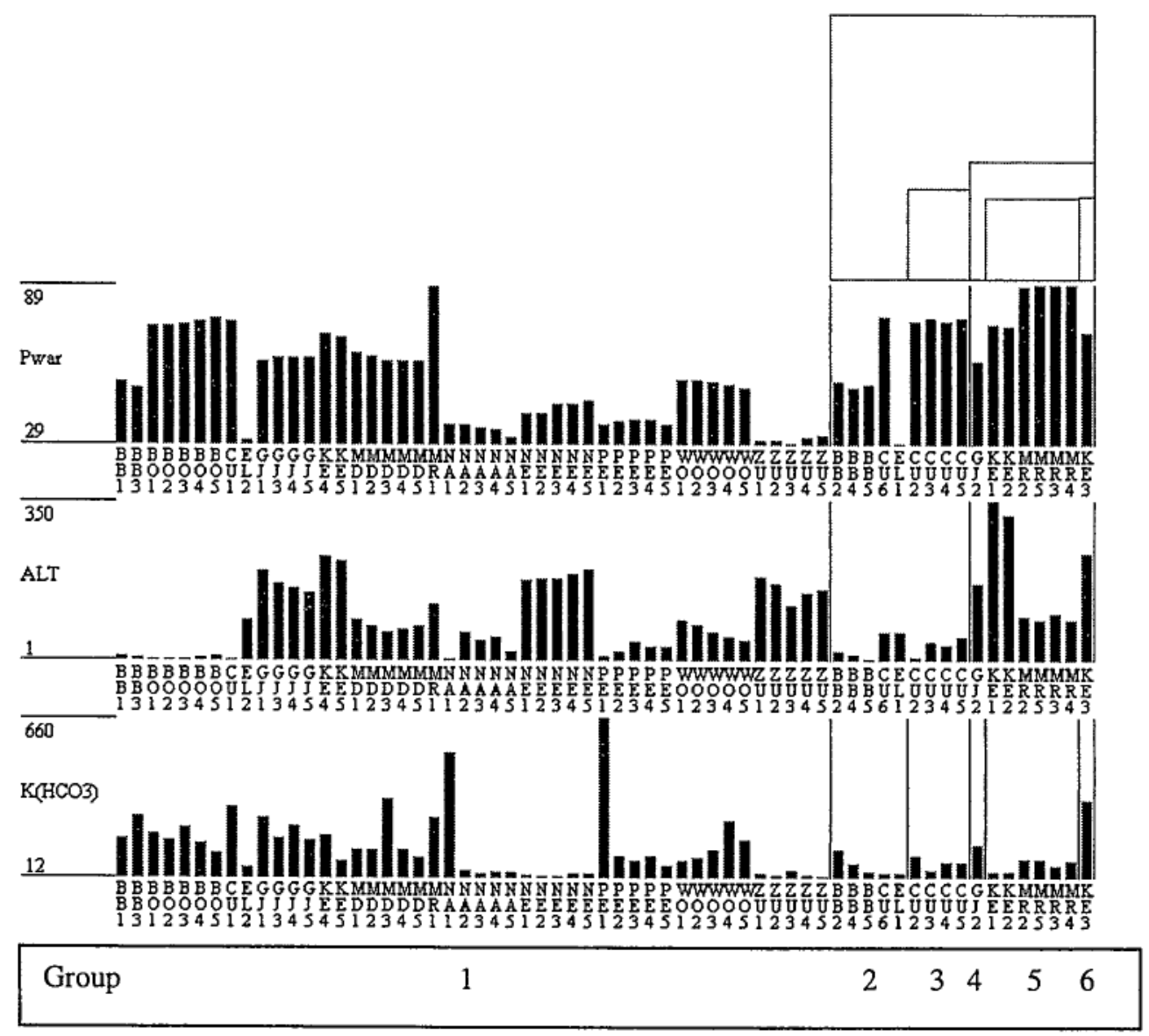

Figure 5 Quadrat attribute values for 'precipitation in the warmest quarter' (Pwar), 'soil potassium' $\left(\mathrm{KHCO}_{3}\right)$ and 'altitude' (ALT) superimposed as histograms on the dendrogram structure derived from the classification of the 63 quadrats in terms of species belonging to assemblage-1. Quadrat codes are printed vertically. 


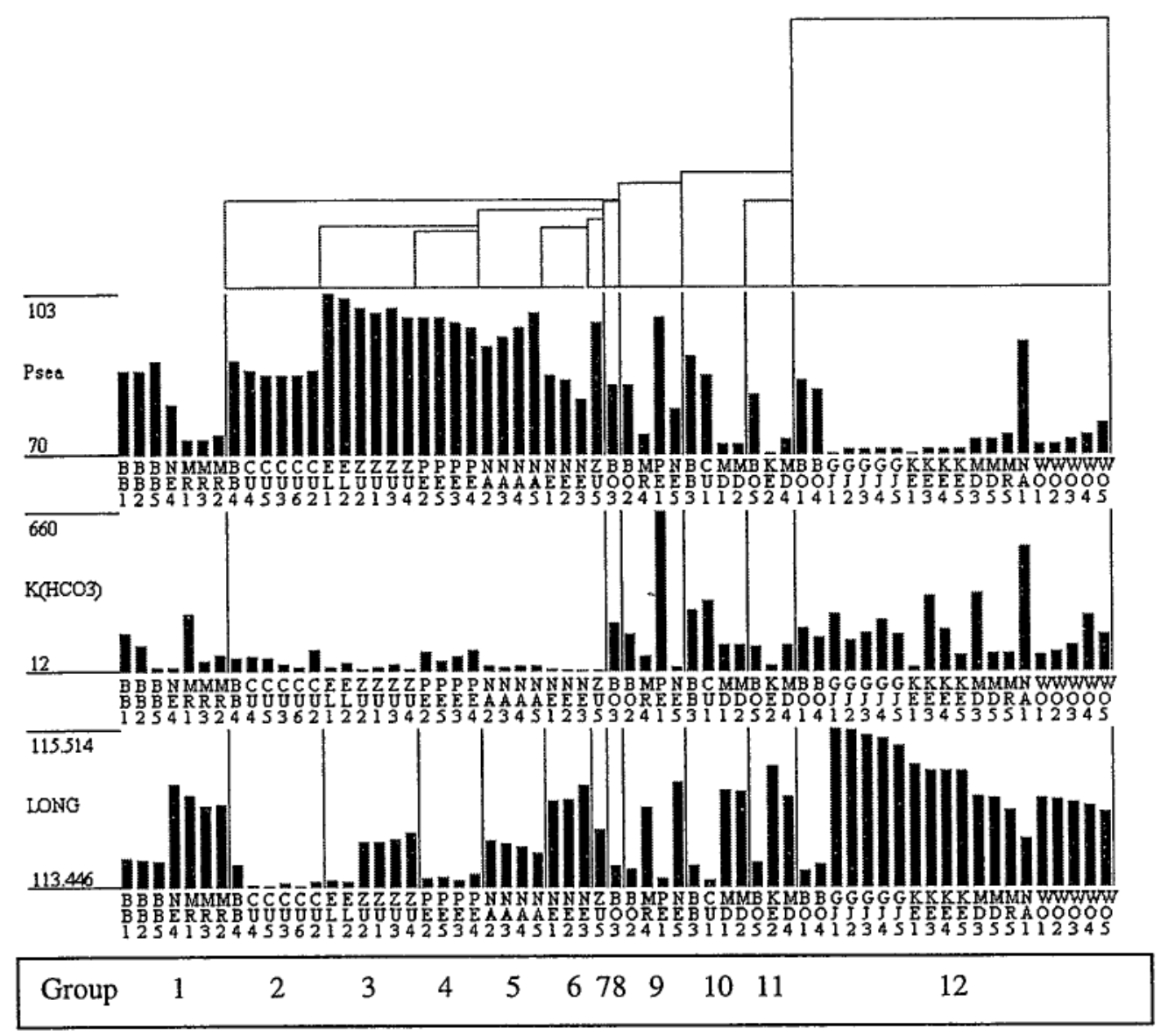

Figure 6 Quadrat attribute values for 'precipitation seasonality' (Pseas), 'soil potassium' $\left(\mathrm{KHCO}_{3}\right)$ and 'longitude' (LONG) superimposed as histograms on the dendrogram structure derived from the classification of the 63 quadrats in terms of species belonging to assemblage-2. Quadrat codes are printed vertically.

Shark Bay (Egernia multiscutata bos and E. kingii). Nine species are snakes or pygopodids, groups poorly sampled by our methods. Although not recorded on any of our quadrats, an Aclys concinna major was found on the road between quadrats NA3 and NA4, a single Antaresia stimsoni on a road in Carnarvon, and a Varanus giganteus was captured 100 m east of MD3.

Unlike mammals, there is no reason to suppose that any frog or reptile species has become extinct in the study area during the last 200 years, despite extensive loss of top soil, a major reduction in vegetative cover across most of the area, and the introduction of a variety of mammalian herbivores and predators. Quadrats visibly degraded by goats, stock and/or rabbits were not significantly poorer in species than those elsewhere in the study area. Similar reptile storage-effects (Warner and Chesson, 1985) have been reported from the northern Nullarbor $\left(30^{\circ} 00^{\prime} \mathrm{S}, 127^{\circ} 45^{\prime} \mathrm{E}\right)$, where areas that had been virtually stripped of vegetation for more than a decade had retained at least $40 \%$ of their reptile fauna (McKenzie et al., 1987; Wyrwoll, Stoneman, Elliott and Sandercock, 2000). Landsberg et al.
(1997) reached a similar conclusion from a broad ranging study of Australian pastoral regions, and cited North American studies that yielded similar conclusions - grazing significantly reduces the abundance of reptiles, but not their species richness (Jones, 1981; Bock et al., 1990). Nevertheless, Saunders et al. (1991) have pointed out that presence of species does not necessarily imply their persistence in the longer term; most large reptiles are long-lived and nearly all reptiles have low, and only intermittent, nutrient requirements. Thus, individuals may remain long after their populations are no-longer viable.

\section{Data Quality}

During this study we attempted to make exhaustive inventories of 16 hectare quadrats, rather than of large, environmentally heterogeneous areas comparable to the "compartments" discussed by Gibbons et al. (1997). Nevertheless, long-term studies of Australian reptiles have shown that species continue to be added to quadrat-lists even after several years of regular sampling, using pittraps and drift-fences as well as hand-foraging 


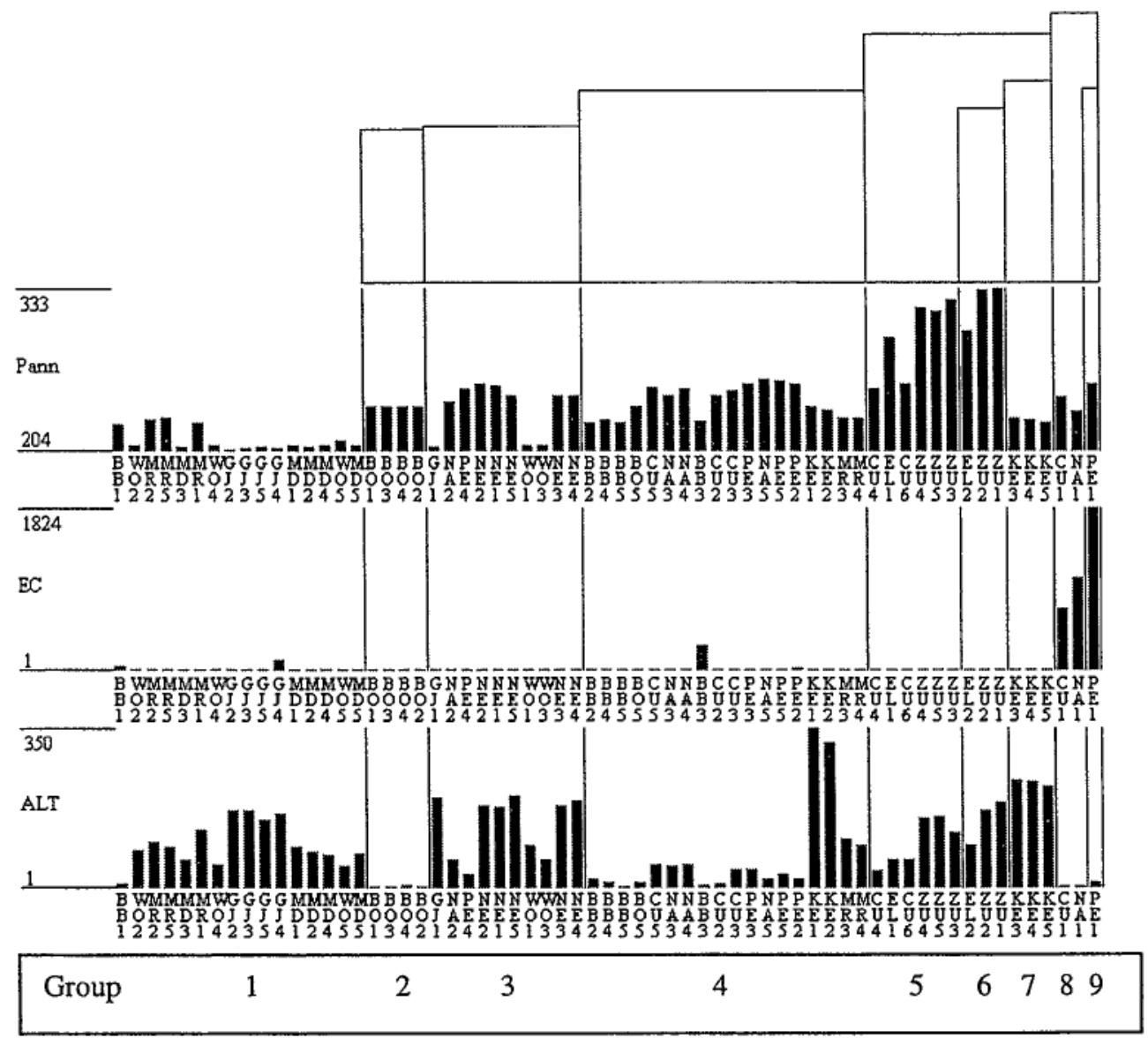

Figure 7 Quadrat attribute values for 'annual average precipitation' (Pann), 'soil electrical conductivity' (EC) and 'altitude' (ALT) superimposed as histograms on the dendrogram structure derived from the classification of the 63 quadrats in terms of species belonging to assemblage-3. Quadrat codes are printed vertically.

methods (How, 1998; James, 1994). Our trap-return analysis revealed a similar pattern. Even on the last day of the sampling programme, an additional species was detected at 23 of the 63 quadrats (Figure 2), although the 6\% average improvement over the final sampling session (during March 1996) indicated that the sampling returns had diminished.

Comparison with the historical data revealed that our quadrat sampling methods were more effective for detecting the presence or absence of dragons ( $94 \%$ of the previously known fauna), geckoes $(85 \%)$, varanids $(80 \%)$, skinks $(79 \%)$ and pygo-

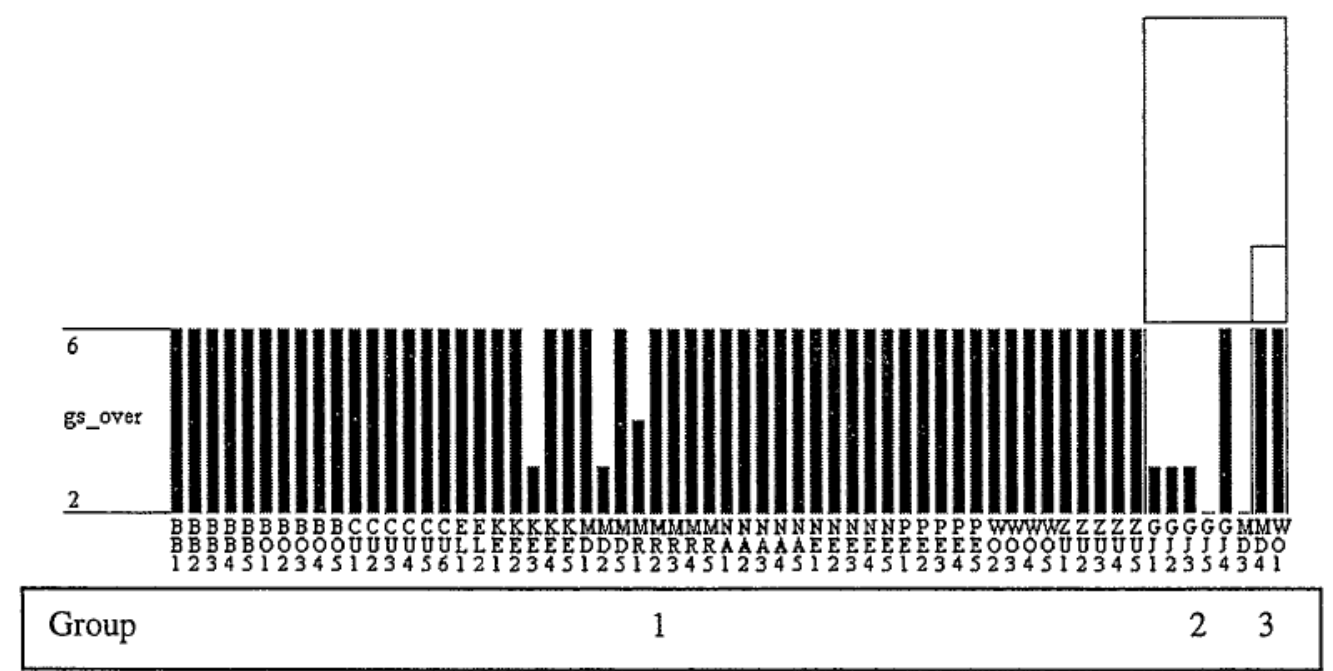

Figure 8 Quadrat attribute values (ordinal) for 'over-bank stream flow' (gs_over) superimposed as an histogram on the dendrogram structure derived from the classification of the 63 quadrats in terms of species belonging to assemblage-4. Quadrat codes are printed vertically. 
Figure 9 Data matrix of ecological taxa re-ordered according to species co-occurrences at the same quadrats and similarities in the overall composition of the quadrats. Quadrat codes are printed vertically. Taxa dendrogram is included to indicate classification structure down to the 22 group level.

QUADRAT CODES

BWMMMMWWNNWNNMWBBBB | GMGGGG | KKK | BBBBCCCCCNNNPPZPPNNZ | EZEZZ | KKMMMM |BCP |N BODDDDOOEEOEEROOOOO JDJJJJ EEE BBBOUUUUUAAAEEUEEAEU LULUU | EERRRR BUE A

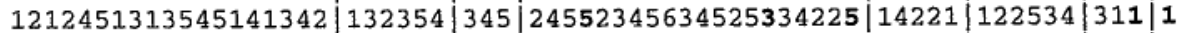

Acanthophis pyrrhus........ Diporiphora winneckei. ASSEMBLAGE-1

APRASIA CTENOT_2.

Varanus gouldi...

Ctenotus calurus.

Ctenophorus rubens.

Ctenotus pantherinus..

Ctenophorus clayi.

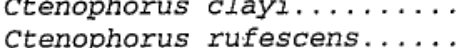

Ctenotus piankai.

Cyclorana platycephalus.... ASSEMBLAGE-2

Crenadactylus aff. ocellatus SNAKE_L1

CTENOP_ 1 .

LERIST 4 .

MORETH_2

LERIST_2

CTENOT_1.

DIPALPYGO.

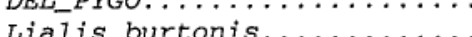

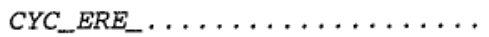

CYC_ERE

CRYPTOBL

PSEUDOPH.

Diplodactylus ornatus.

pletholax gracilis.edelensis

.TYMPANOC.

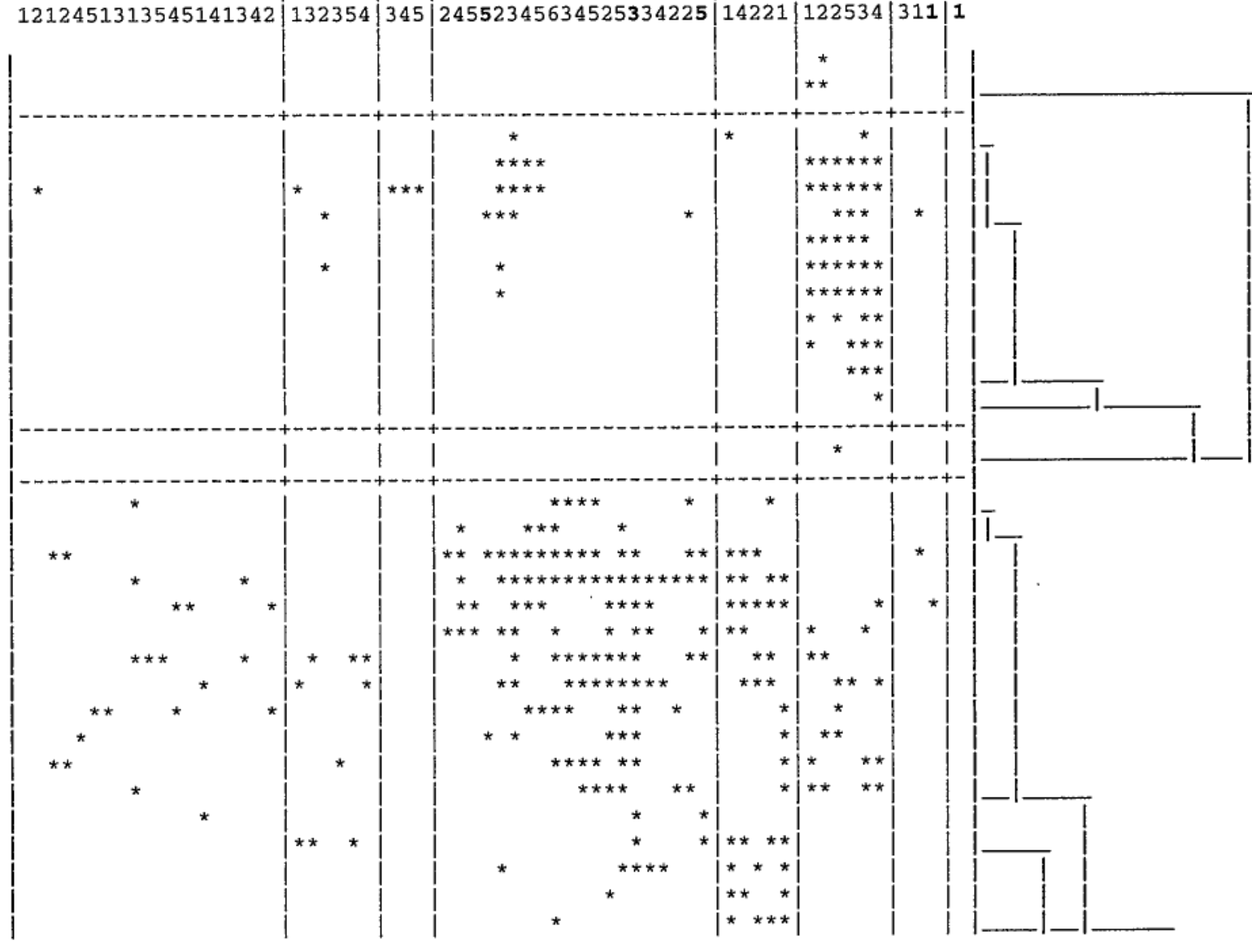


ASSEMBLAGE-3

CTENOP_2.

LERIST 5

VAR SMAL

STROPH I.

STAKE 53.

GEHYRA_

MENET 1

LERIST_3.

LERIST_6.

Nephrurus levis.

Pogona minor.

Heteronotia binoei.

LERIST_1. .

Moloch horridus.

SNAKE_S1.

TILIQUA

DIP RHYN.

Ctenotus schomburgi

CLenotus

SNAKE_BL

NEOBATRA

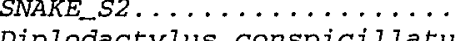

Diplodacty BGRIA

ASSEMBLAGE-

Ctenophorus caudicinctus. . .

Antaresia perthensis. .

Morethia ruficauda exquisita

Cyclorana maini.

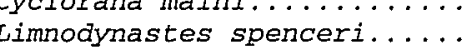

Lerista gascoymensis..

Neobatrachus fulvus.

Litoria rubella...

strophurus michaelseni.

Amphibolurus longirostris..

Morethia butleri.

Neobatrachus pelobatoides.
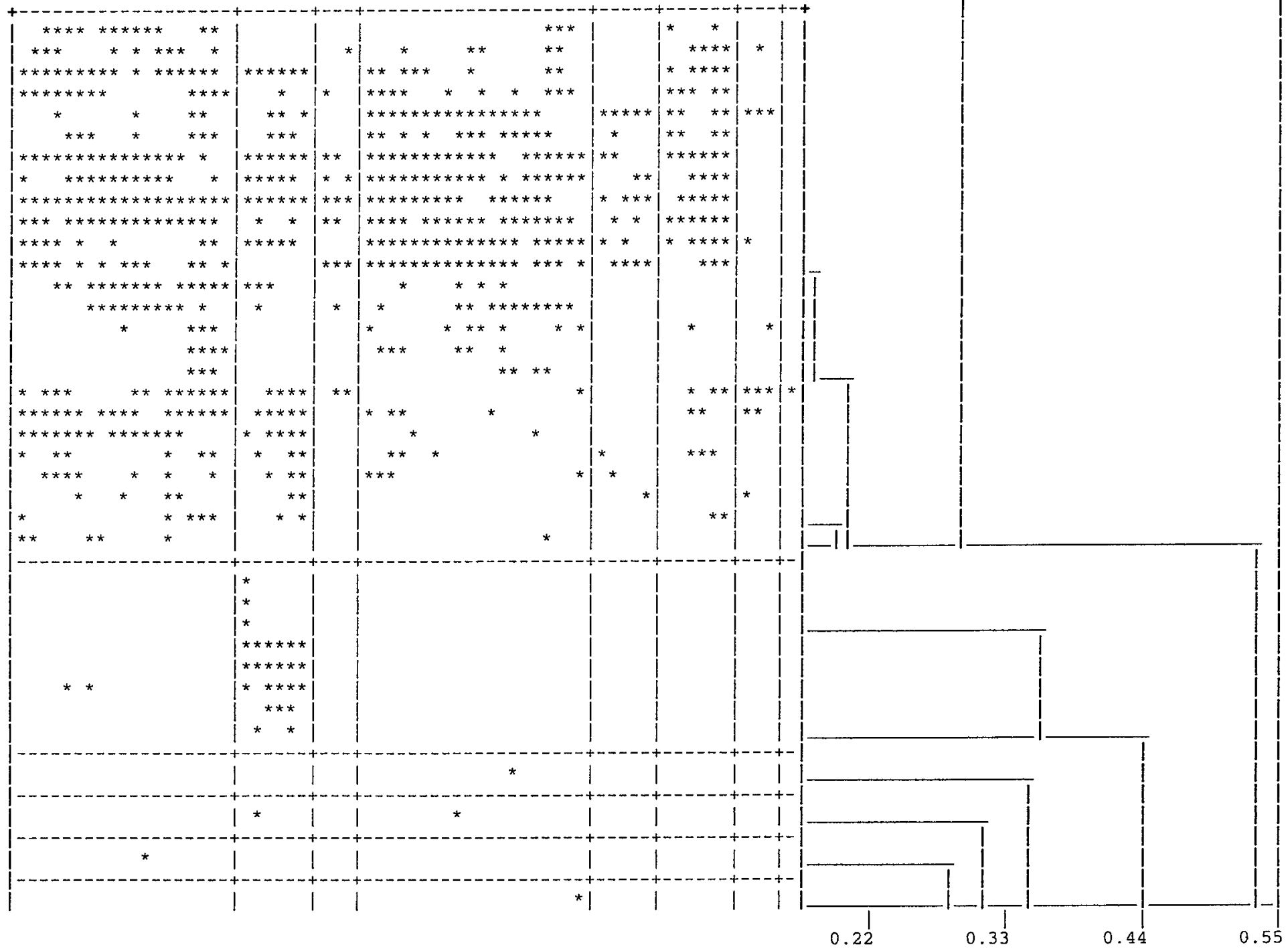

DISSIMILARITY COEFFICIENT 
podids (77\%), than for frogs $(73 \%)$ and snakes (65\%). Although the snake and pygopodid inventories of the quadrats were likely to be too unreliable for quantitative analysis, the gecko and frog percentages are probably under-estimated because the three gecko species and two of the four frogs that were overlooked have geographical ranges that barely intrude into our study area.

\section{Richness}

One hundred and thirty-three species were recorded on quadrats during our sampling programme, an average of $16.3 \pm 5.6(\mathrm{sd}), \mathrm{n}=63$ species per quadrat (over three seasons). Similar species richness was recorded from quadrats of equivalent size in the adjacent Murchison and Coolgardie Bioregions elsewhere in the arid zone of southern Western Australia (12.2 $\pm 4.5, n=109$ species per quadrat, sampled using equivalent methods) (Dell and How, 1985; How et al., 1988; McKenzie et al., 1992, 1994, 1995).

The study area's total herpetofaunal species richness comes from four sources.

1. The region straddles the biogeographic transition from the South-western to the Eremean Phytogeographic Province, and includes components of the herpetofaunas of both regions.

2. Examples of the sand environments that dominate the Eremean (Australia's red centre) are well represented in the study area, as are a variety of the semi-arid woodlands, sand heaths and coastal habitats of the South-west.

3. Rich Lerista assemblages were associated with the Eucalyptus and/or Acacia litter-patches found on virtually all non-saline quadrats in the study area, even quadrats with only a thin sandy soil A-horizon $(3.8 \pm 1.4, \mathrm{n}=56$ Lerista species per quadrat). Seven species were recorded on some quadrats (BB4, CU3, PE4 and ZU3). Kendrick (1991) concluded that there has been a significant radiation of Lerista taxa in the study area.

4. The arid-adapted genera Diplodactylus, Ctenophorus, Ctenotus and Lerista are very diverse $(7,10,18$ and 22 species respectively) with high levels of syntopy among Ctenotus and Lerista species, particularly on the 14 quadrats which represented the red sand-hummock grass environments that dominate Australia's arid zone: an average of 3.4 Ctenotus and 4.4 Lerista species per quadrat. In equivalent sandhummock grass habitats of the Great Victoria Desert, elsewhere in temperate Western Australia, Pianka (1969b) noted up to seven Ctenotus species in "ecologic sympatry".

Heatwole and Taylor (1987: 215 et seq.) reviewed the literature on factors that are known to affect richness in reptile assemblages. A range of factors, including rainfall, amount of sunshine, structural complexity in vegetation and productivity have been shown to have a positive correlation with species richness. In arid regions of Australia, richness has also been explained in terms of environmental heterogeneity, the presence of hummock grass, occupation by reptiles of niches elsewhere occupied by other animal taxa, and low nutrients (poor soils) limiting homeotherms (see Heatwole and Taylor, 1987: 220; Morton and James, 1988; Pianka, 1989; but also see Rosenzweig, 1992).

The 14 quadrats representing these low nutrient, red sand with hummock-grass environments in the study area had the richest assemblages we encountered; an average of $21.5 \pm 4.8$ (sd) herpetofaunal species (BB4, PE2,5, CU2-5, MR2-5, NE1 and KE1-2; Table 9). Rich reptile assemblages have previously been reported from such hummock grasslands on red sand in the Great Victoria Desert (Pianka, 1969a; Armstrong, 1992). For instance, Pianka (1969a) reported 39 species of lizard coexisting in sympatry in a square kilometre of sandridge habitat, and at several sandplain sites he reported up to 30 species. Elsewhere in Central Australia, Fyfe (1985) found that hummock grasslands on red sand surfaces supported a greater number of reptile species than did the Mulga shrublands that occurred on finer textured soils in the same area.

\section{Patterns in the Species Composition of Assemblages}

Scale is important in determining which environmental attributes emerge as significant correlates with compositional patterns (Dale, 1983; Whitmore, 1984). Regional studies have usually linked compositional patterns to climatic and/or geological categories (Ashton, 1976; McKenzie et al., 1987, 1991a, 1992, 1994; McKenzie and Rolfe, 1995). In more geographically restricted studies, topographic setting and lithology become important (Whitmore, 1984)

Several distinct stepwise structures dominated both the quadrat and the species classification dendrograms (Figures 3 and 4 ). In the context of our study, this would occur if the component species were responding to different environmental gradients and/or to the same gradients differently. On the reasoning that species which usually cooccur are more likely to be responding to the same environmental gradient/s than are species with different patterns of co-occurrence (see McKenzie et al., 1989: 255-6), we sought to untangle the biogeographical processes by treating the four species assemblages derived from the overall analysis as independent data-sets, and analysing them separately (cf. McKenzie et al., 1989, 1991a; McKenzie and Belbin, 1991). 
Strong relationships between herpetofaunal patterns and environmental attributes emerged for all assemblages. The species richness of each assemblage at any site fitted Poisson error models, with logarithmic links (Crawley, 1993; Nicholls, 1989) that usually involved a climatic, a soil and a geographical parameter:

- assemblage-1 (precipitation in the warmest quarter, modified by soil potassium and altitude),

- assemblage-2 (precipitation seasonality, modified by soil potassium and longitude),

- assemblage-3 (annual average precipitation, modified by electrical conductivity and altitude), and

- assemblage-4 (unchannelled over-bank stream flow).

As expected, the richness of each assemblage related to different sets of attributes, although soil potassium and altitude were among the attributes significant for two of the three assemblages modelled. Potassium is readily leached from soil profiles by rainfall or flood water and provides a sensitive measure of fertility ( $T$. Stoneman, personal communication). The sand soil profiles were low in Potassium (Kendall's Tau $=-0.42$, p. $<0.001$ ), and the positive relationship between sandiness and species richness probably relates to the radiation in genera such as Ctenotus and Lerista that has occurred in the sand environments that dominate arid Australia. This radiation was discussed above, and by Aplin et al. (in press).

As a linear predictor, however, soil potassium is of little practical value for un-sampled sites because data on soil chemistry are only available at a few points in the study area. The tight inter-correlation between soil potassium and textural shear strength (Kendall's tau $=0.45^{* * *}$ ) despite six $(10 \%)$ missing values in the latter, suggests that shear strength should be a useful surrogate for field work. Electrical conductivity, the other significant soil attribute, is a measure of salinity. Numerous previous studies have found that quadrats with highly saline soils are species-poor, although compositionally distinctive (e.g. How et al., 1998; McKenzie and Rolfe, 1995).

Within each assemblage, richness provided a reasonable surrogate of composition because regionally-nested patterns in species composition (cf. Patterson and Brown, 1991) are visible in each assemblage (see Figure 3). These are not perfectly defined due in part at least to localised patterns in allopatry in addition to the sampling errors related to the snakes, varanids and pygopodids (see Rolfe and McKenzie, 2000). Further, well-defined nested patterns in species composition would not be expected for assemblages where richness is influenced by the interaction of several divergent environmental gradient vectors.
In combination with our univariate analyses, the GLIM analyses revealed that patterns in the species composition of the herpetofaunal assemblages were being influenced by environmental processes operating at two geographical scales: (1) a biogeographical scale related to the differences between the Eremean and South-western faunas, and corresponding to the study area's arid-to-mesic and tropical-to-temperate climatic gradients, but mitigated by coastal effects in northern parts of the study area, and (2) a local scale related to topographic and soil attributes.

Localised patterns of allopatry among closely related species belonging to the more diverse genera, and unevenness in taxonomic discrimination within different genera, were additional sources of variation in assemblages- 2 and -3 . Our ecologically re-defined taxa virtually eliminated this variation without losing ecological discrimination, indicating that the reserve system will need to sample the geographical extent of the various rainfall and soil gradients identified by the analyses, if evolutionary processes are to be protected.

\section{ACKNOWLEDGEMENTS}

P. Boglio, A.A. Burbidge, A.H. Burbidge, A. Desmond, P.J. Fuller, N. Hall, R.E. Johnstone, B. Marion, W.P. Muir, R. Smith, and P. Stone assisted in the sampling program. Mike Lyons prepared the map and Paul Gioia ran the computer package ANUCLIM to generate the climatic data-set. We thank A.O. Nicholls and M.R. Williams for statistical advice, and A.H. Burbidge, R.A. How and P.G. Kendrick for their comments on the manuscript.

Funding was provided by the Commonwealth through the National Reserves System Co-operative Program of the Australian Nature Conservation Agency (now Environment Australia), the Western Australian Department of Conservation and Land Management and the Western Australian Museum.

\section{REFERENCES}

Aplin, K.P., Adams, M. and Cowan, M.A. (in press). Systematics and biogeography of the herpetofauna of the Carnarvon region of Western Australia. Records of the Western Australian Museum Supplement.

Armstrong, G.P. (1992). Reptiles. In P.G. Copley and C.M. Kemper (eds), A Biological Survey of the Yellabinna Region, South Australia, in October 1987, 163-179. National Parks and Wildlife Service. Department of Environment and Land Management, South Australia.

Ashton, P.S. (1976). Mixed dipterocarp forest and its variation with habitat in Malayan lowlands: a reevaluation at Pasoh. Malay Forester 39: 56-72. 
Austin, M.P. (1984). Problems of vegetation analysis for nature conservation. In $\mathrm{K}$. Myers and C.R. Margules (eds), Survey Methods for Nature Conservation, 1: 101130. CSIRO Division of Water and Land Resources: Canberra.

Beard, J.S. (1975). Pilbara. Explanatory Notes to Sheet 5, 1:1 000000 Series. Vegetation Survey of Western Australia. University of Western Australia Press, Nedlands.

Beard, J.S. (1976). Murchison. Explanatory Notes to Sheet 6, 1:1000000 Series. Vegetation Survey of Western Australia. University of Western Australia Press, Nedlands.

Beard, J.S. (1980). A new phytogeographic map of Western Australia. Western Australian Herbarium Research Notes 3: 37-58.

Belbin, L. (1980). TWOSTEP: a program incorporating asymmetric comparisons that uses two steps to produce a dissimilarity matrix. Technical Memorandum 80/9. CSIRO Division of Land Use Research, Canberra.

Belbin, L. (1995). PATN Technical Reference. CSIRO Division of Wildlife and Ecology, Canberra.

Bock, C.E., Smith, H.M. and Bock, J.H. (1990). The effect of livestock grazing upon abundance of the lizard, Sceloporus scalaris, in southeastern Arizona. Journal of Herpetology 24: 445-446.

Burbidge, A.A. and George, A.S. (1978). The flora and fauna of Dirk Hartog Island, Western Australia. Journal of the Royal Society of Western Australia. 60: 7190.

Burbidge, A.A., Fuller, P.J. and Cashin, K. (1980). The wildlife of the proposed Toolonga nature reserve, Shark Bay Shire, Western Australia. Report No. 39: 136. Department of Fisheries and Wildlife, Western Australia.

Burbidge, A.A. and McKenzie, N.L. (1989). Patterns in the modern decline of Western Australia's vertebrate fauna: causes and conservation considerations. Biological Conservation 50: 143-198.

Crawley M.J. (1993). GLIM for Ecologists. Blackwell Scientific Publications, Oxford.

Czekanowski, J. (1932). Coefficient of racial likeness, und durchschnittliche differenz. Anthropologischer Anzeiger 9: 227-249.

Dale, P.E.R. (1983). Scale problem in classification: an application of a stochastic method to evaluate the relative homogeneity of sample units. Australian Journal of Ecology 8: 189-198.

Dell, J. and How, R.A. (1985). Vertebrate Fauna. In The Biological Survey of the Eastern Goldfields of Western Australia. Part 3: Jackson-Kalgoorlie Study Area, 39-66. Records of the Western Australian Museum Supplement No. 23: 1-168

Douglas, A.M. and Ride, W.D. L. (1962). The reptiles. In A.J. Fraser (ed.), The Results of an Expedition to Bernier and Dorre Islands, Shark Bay, Western Australia in July 1959: 113-119. Western Australia Fisheries Department Fauna Bulletin No. 2: 1-131.

Ehmann, H. (1992). Encyclopedia of Australian Animals: Reptiles. Collins Angus and Robertson, Australia.

Fyfe, G.A. (1985). A comparison of the ground-dwelling vertebrate faunas found in hummock grassland and mulga shrubland in Central Australia. Herpetofauna 16: $49-52$

Gibbons, J.W., Burke, V.J., Lovich, J.E., Semlitsch, R.D., Tuberville. T.D. and Bodie, J.R. (1997). Perceptions of species abundance, distribution, and diversity: lessons from four decades of sampling on a government-managed reserve. Environmental Management 21: 259-268.

Gibson, N., Keighery, G.J. and Lyons, M.N. (2000). The flora and vegetation of the seasonal and perennial wetlands of the southern Carnarvon Basin, Western Australia. Records of the Western Australian Museum Supplement No. 61: 175-199.

Heatwole, H.F. and Taylor, J. (1987). Ecology of Reptiles. Surrey Beatty and Sons, Chipping Norton, NSW.

Harvey, M.S., Sampey, A., West, P.L.J. and Waldock, J.M. (2000). Araneomorph spiders from the southern Carnarvon Basin, Western Australia: a consideration of regional biogeographic relationships. Records of the Western Australian Museum Supplement No. 61: 295321.

How, R.A. (1998). Long-term sampling of an herpetofaunal assemblage on an isolated bushland remnant, Bold Park, Perth. Journal of the Royal Society of Western Australia. 81: 143-148.

How, R.A., Dell, J. and Muir, B.G. (1988). Vertebrate fauna. In The Biological Survey of the Eastern Goldfields of Western Australia. Part 4: Lake Johnston-Hyden Study Area, 44-83. Records of the Western Australian Museum Supplement No. 30: 1-233.

James, C.D. (1994). Spatial and temporal variation in structure of a diverse lizard assemblage in arid Australia. In L.J. Vitt, and E.R. Pianka (eds), Lizard Ecology: Historical and Experimental Perspectives, 287317. Princeton University, New Jersey.

Jones, K.B. (1981). Effects of grazing on lizard abundance and diversity in western Arizona. Southwest Naturalist 26: 107-115.

Keighery, G.J., Gibson, N., Lyons, M.N. and Burbidge, A.H. (2000). The flora and vegetation of the southern Carnarvon Basin, Western Australia. Records of the Western Australian Museum Supplement No. 61: 77154.

Kendrick, P.G. (1989). Two new species of Lerista (Lacertilia: Scincidae) from the Cape Range and Kennedy Range of Western Australia. Journal of Herpetology 23: 350-355.

Kendrick, P.G. (1991). The phylogenetics and comparative ecology of Lerista, Bell 1833; patterns of evolution in a genus of sand swimming skinks. $\mathrm{PhD}$ Thesis. University of Western Australia, Perth.

Landsberg, J., James, C.D., Morton, S.R., Hobbs, T.J., Stol, J., Drew, and Tongway, H. (1997). The effects of artificial sources of water on rangeland biodiversity. Environment Australia and CSIRO, Canberra.

McKenzie, N.L., Rolfe, J.K. and Carter, D. (1987). Reptiles. In N.L. McKenzie and A.C. Robinson (ed.), A Biological Survey of the Nullarbor Region, South and Western Australia in 1984, 179-210. Government Printer, Adelaide.

McKenzie, N.L., Belbin, L., Margules, C.R. and Keighery, G.J. (1989). Selecting representative reserve systems 
in remote areas: a case study in the Nullarbor region, Australia. Biological Conservation 50: 239-261

McKenzie, N.L. and Belbin, L. (1991). Kimberley rainforest communities: reserve recommendations and management considerations. In N.L. McKenzie, R.B. Johnstone and P.G. Kendrick (eds), Kimberley Rainforests of Australia, 453-468. Surrey Beatty and Sons Pty Ltd, Chipping Norton, NSW.

McKenzie, N.L., Belbin, L., Keighery, G.J. and Kenneally, K.F. (1991a). Kimberley rainforest communities: patterns of species composition and Holocene biogeography. In N.L. McKenzie, R.B. Johnstone and P.G. Kendrick (eds), Kimberley Rainforests of Australia, 423-451. Surrey Beatty and Sons Pty Ltd, Chipping Norton, NSW.

McKenzie, N.L., Robinson, A.C. and Belbin, D.L. (1991b). Biogeographic survey of the Nullarbor district, Australia. In C.R. Margules and M.P Austin (eds), Nature Conservation: Cost Effective Biological Surveys and Data Analysis. CSIRO Division of Wildlife and Ecology, Canberra.

McKenzie, N.L., Rolfe, J.K. and Youngson, W.K. (1992). Vertebrate fauna. In The Biological Survey of the Eastern Goldfields of Western Australia. Part 8. The Kurnalpi Kalgoorlie Study Area, 37-64. Records of the Western Australian Museum Supplement No. 41: 1-125.

McKenzie, N.L., Rolfe, J.K. and Youngson, W.K. (1994). Vertebrate fauna. In The Biological Survey of the Eastern Goldfields of Western Australia. Part 10. The SandstoneSir Samuel and Leonora - Laverton Study Areas, 51-85. Records of the Western Australian Museum Supplement No. 47: 1-166.

McKenzie, N.L. and Rolfe, J.K. (1995). Vertebrate fauna. In The Biological Survey of the Eastern Goldfields of Western Australia. Part 11. The Boorabbin-Southern Cross Study Area, 31-65. Records of the Western Australian Museum Supplement No. 49: 1-167.

McKenzie, N.L., Hall, N. and Muir, W.P. (2000). Nonvolant mammals of the southern Carnarvon Basin, Western Australia. Records of the Western Australian Museum Supplement No. 61: 479-510.

McMahon, J.P., Hutchinson, M.F., Nix, H.A. and Ord, K.D. (1995). ANUCLIM Users Guide, Version 1. Centre for Resource and Environmental Studies, Australian National University, Canberra, Australia.

Morton, S.R. and James, C.D. (1988). The diversity and abundance of lizards in arid Australia: a new hypothesis. The American Naturalist 132: 237-256.

NAG (1986). The Generalised Linear Interactive Modelling System. Release 4.0 Manual. Numerical Algorithms Group, Oxford.

Nicholls, A.O. (1989). How to make biological surveys go further with generalised linear models. Biological Conservation 50: 51-75.

Patterson, B.D. and Brown, J.H. (1991). Regionally nested patterns of species composition in granivorous rodent assemblages. Journal of Biogeography 18: 395-402.

Payne, A.L., Curry, P.J. and Spencer, G.F. (1987). An inventory and condition survey of the rangelands in the Carnarvon Basin, Western Australia. Technical Bulletin No. 78. Department of Agriculture, South Perth.

Pianka, E.R. (1969a). Habitat specificity, speciation, and species density in Australian desert lizards. Ecology, 50: 498-502.

Pianka, E.R. (1969b). Sympatry of desert lizards (Ctenotus) in Western Australia. Ecology, 50: 10121030.

Pianka, E.R. (1989). Desert lizard diversity: additional comments and some data. The American Naturalist 134: 344-364.

Rosenzweig, M.L. (1992). Species diversity gradients: we know more and less than we thought. Journal of Mammalogy 73: 715-730.

Rolfe, J.K. and McKenzie, N.L. (2000). Comparison of methods used to capture herpetofauna: an example from the Carnarvon Basin. Records of the Western Australian Museum Supplement No. 61: 361-370.

Saunders, D.A., Hobbs, R.J. and Margules, C.R. (1991). Biological consequences of ecosystem fragmentation: a review. Conservation Biology 5: 18-32.

Sneath, P.H.A. and Sokal, R.R. (1973). Numerical Taxonomy. The principals and practice of numerical classification. W.H. Freeman, San Francisco.

Storr G.M. (1991a). Four new members of the Lerista nichollsi complex (Lacertilia: Scincidae). Records of the Western Australian Museum 15: 139-147.

Storr G.M. (1991b). Partial revision of Lerista macropisthopsis (Lacertilia: Scincidae). Records of the Western Australian Museum 15: 149-161.

Storr G.M. (1991c). A new sub-species of Lerista planiventralis (Lacertilia: Scincidae) from Western Australia. Records of the Western Australian Museum 15: $483-485$.

Storr, G.M. and Harold, G. (1978). Herpetofauna of the Shark Bay region, Western Australia. Records of the Western Australian Museum 6: 449-467.

Storr, G.M. and Harold, G. (1980). Herpetofauna of the Zuytdorp Coast and hinterland, Western Australia. Records of the Western Australian Museum 8: 359-375.

Storr, G.M. and Harold, G. (1984). Herpetofauna of the Lake Macleod Region. Records of the Western Australian Museum 11: 173-189.

Storr, G.M. and Harold, G. (1990). Amphibians and reptiles of the Shark Bay area, Western Australia. In P.F. Berry, S.D. Bradshaw and B.R. Wilson (eds), Research in Shark Bay. Report of the France-Australe Bicentenary Expedition Committee, 279-285. Western Australian Museum, Perth.

Thackway, R. and Cresswell, I.D. (1995) (eds). An interim biogeographic regionalisation for Australia. A framework for establishing the national system of reserves, Version 4.0. Australian Nature Conservation Agency, Canberra.

Tyler, M.J., Smith, L.A. and Johnstone, R.E. (1994). Frogs of Western Australia. Western Australian Museum, Perth.

Warner, R.R. and Chesson, P.L. (1985). Co-existence mediated by recruitment fluctuations: a field guide to the storage effect. The American Naturalist 125: 769787.

Werner, F. (1909). Reptilia, exkl. Geckonidae und Scincidae. In W. Michaelsen and R. Hartmeyer (eds), Die Fauna Sudwest-Australiens 2: 251-278. 
Whitmore, T.C. (1984). Tropical Rainforests of the Far East. Clarendon Press, Oxford.

Wilson, S.K. and Knowles, D.G. (1988). Australia's Reptiles. A Photographic Reference to the Terrestrial Reptiles of Australia. Collins, Australia.

Wyrwoll, K.-H., Courtney, J. and Sandercock, P. (2000).

The climatic environment of the Carnarvon Basin, Western Australia. Records of the Western Australian Museum Supplement No. 61: 13-27.
Wyrwoll, K.-H., Stoneman, T., Elliott, G. and Sandercock, P. (2000). Geoecological setting of the Carnarvon Basin, Western Australia: geology, geomorphology and soils of selected sites. Records of the Western Australian Museum Supplement No. 61: 29-75.

Manuscript received 21 April 1998; accepted 10 September 1998. 